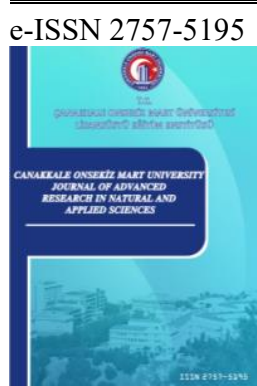

Çanakkale Onsekiz Mart University

Journal of Advanced Research in Natural and Applied Sciences

Open Access

\title{
Edirne İli Özelinde 2019 ve 2007 Türk Deprem Yönetmeliklerine Göre Yatay Tasarım İvme Spektrumlarının Değişiminin İncelenmesi
}

\author{
Burak Özşahin ${ }^{1 *}$ \\ ${ }^{1}$ Mimarlık Bölümü, Mimarlık Fakültesi, Kırklareli Üniversitesi, Kırklareli, Türkiye
}

\begin{abstract}
Makale Tarihçesi
Gönderim: 25.04 .2021

Kabul: $\quad 04.08 .2021$

Yayım: $\quad 15.12 .2021$
\end{abstract}

Araştırma Makalesi

\begin{abstract}
$\ddot{\mathbf{O} z}$ - Deprem mühendisliği ve teknolojideki gelişmeler, Türkiye ve dünyada yaşanan depremlerden elde edilen tecrübeler sonucu Deprem Bölgelerinde Yapılacak Binalar Hakkında Yönetmelik 2007 yerini Türkiye Bina Deprem Yönetmeliği 2019'a bırakmıştır. Türkiye Bina Deprem Yönetmeliği 2019 ile birlikte 1996 yılından beri kullanılmakta olan deprem bölgeleri haritası da yürürlükten kaldırılarak yerine yeni hazırlanan Türkiye Deprem Tehlike Haritaları yürürlüğe girmiş̧ir. Bu çalışmada Deprem Bölgelerinde Yapılacak Binalar Hakkında Yönetmelik 2007'den Türkiye Bina Deprem Yönetmeliği 2019'a geçilirken yatay tasarım ivme spektrumlarındaki değişim Edirne ili özelinde incelenmiştir. Bu amaçla Deprem Bölgelerinde Yapılacak Binalar Hakkında Yönetmelik 2007'ye göre 2., 3. ve 4. deprem bölgesinde yer alan Edirne merkezi ve ilçeleri için Deprem Bölgelerinde Yapılacak Binalar Hakkında Yönetmelik 2007 ve Türkiye Bina Deprem Yönetmeliği 2019'a göre yatay tasarım ivme spektrumları farklı zemin sınıfları ve deprem yer hareketi düzeyleri için ayrı ayrı oluşturularak ivme spektrumlarının, köşe periyotlarının, koordinata dayalı spektrum katsayılarının farklı zemin sınıflarına göre değişimi irdelenmiştir. Çalışmada elde edilen karşılaştırmalı sonuçlar, Türkiye Bina Deprem Yönetmeliği 2019'a göre Edirne merkezi ve ilçelerinin tamamında yatay tasarım spektral ivmelerinin Deprem Bölgelerinde Yapılacak Binalar Hakkında Yönetmelik 2007’ye göre daha büyük değerler aldığını göstermiştir. Edirne merkezi ve ilçeleri için elde edilen sonuçlar Türkiye Bina Deprem Yönetmeliği 2019'un Deprem Bölgelerinde Yapılacak Binalar Hakkında Yönetmelik 2007’ye göre güvenli tarafta kaldığı söylenebilir.
\end{abstract}

Anahtar Kelimeler - Deprem tehlike haritası, Edirne, spektrum eğrisi, tasarım ivme spektrumu, Türkiye bina deprem yönetmeliği

\section{Investigation of the Acceleration Spectra Changes in Edirne Province According to 2007 and 2019 Turkish Building Earthquake Codes}

\author{
Article History \\ Received: $\quad 25.04 .2021$ \\ Accepted: $\quad 04.08 .2021$ \\ Published: $\quad 15.12 .2021$
}

Research Article
${ }^{1}$ Department of Architecture, Faculty of Architecture, Kırklareli University, Kırklareli, Turkey

Keywords - Earthquake hazard map, Edirne, spectrum curve, design acceleration spectrum, Turkish building earthquake code

\footnotetext{
1 (D) burak.ozsahin@klu.edu.tr

*Sorumlu Yazar / Corresponding Author
} 


\section{Giriş}

Depreme dayanıklı bina tasarımda amaç, binaların kullanım ömrü boyunca bulunduğu bölgede olması beklenen en büyük depremde göçmeden ayakta kalabilmesini ve can güvenliğini sağlamaktır (Darılmaz, 2018). Binalara etki edecek deprem yükleri, dinamik ve statik analiz yöntemleri kullanılarak, iki farklı şekilde hesaplanmaktadır. Yapısal analiz süresini kısaltmak ve işlemleri kolaylaştırmak amacıyla dinamik analiz yöntemi yerine statik analiz yöntemi yaygın olarak kullanılmaktadır (Koçer, Nakipoğlu, Öztürk, Al-Hagri ve Arslan, 2018). Düzensizlik içermeyen ya da çok fazla düzensizliği olmayan, az katlı binaların deprem yüklerinin hesabında kullanılan eşdeğer deprem yükü yönteminde binaya etkiyecek deprem yükü, binanın doğal titreşim periyodu için tasarım spektrum eğrisine bağlı olarak belirlenen tasarım ivme değeri ile binanın kütlesi çarpılarak bulunmaktadır. Binaya etki edecek deprem yükü bina periyodu ve spektrum eğrisinin bir fonksiyonudur. Depreme dayanıklı bina tasarımı ve analizi, her ülkenin kendi koşullarına göre hazırlanan deprem yönetmelikleri ile sağlanmaktadır. Tüm dünyada deprem yönetmelikleri, deprem ve yapı mühendisliği alanındaki gelişmeler 1şı̆̆ında zaman zaman revize edilmekte veya yenilenmektedir (İncetaş ve Tanrıkulu, 2002). Türkiye'de Resmi Gazete'de 18.03.2018 tarihinde yayınlanarak 01.01.2019 tarihinde yürürlüğe giren Türkiye Bina Deprem Yönetmeliği 2019 (TBDY 2019) ile birlikte Deprem Bölgelerinde Yapılacak Binalar Hakkında Yönetmelik 2007 (DBYBHY 2007) yürürlükten kalkmıştır. TBDY 2019'un yürürlüğe girmesiyle birlikte 1996 yılından beri kullanılan Deprem Bölgeleri Haritası da yürürlükten kaldırılarak, yerine Türkiye Deprem Tehlike Haritalar1 2019 (TDTH 2019) yürürlüğe girmiştir (Seyrek, 2020; AFAD, 2021). TDTH 2019'da deprem bölgeleri haritalarında olduğu gibi sabit katsayılar ile çalışmak yerine kısa periyod ve uzun periyod için ayrı ayrı olmak üzere binanın bulunduğu koordinatlara dayalı ivme parametreleriyle deprem hesabı yapılmaktadır (Nemutlu, Balun, Benli ve Sar1, 2020).

Deprem bölgeleri haritasından Türkiye Deprem Tehlike Haritaları 2019'a (TDTH 2019) geçişin yeni olması sebebiyle bu konuyla ilgili yapılan sınırlı sayıda çalışma aşağıda kısaca özetlenmiştir.

Şahin, Durucan ve Durucan (2020) çalışmalarında TDY 2017 deprem bölgeleri haritasından kontur içerikli TDY 2018 deprem tehlike haritasına geçilmesi nedeniyle meydana gelen değişikliklerin binalar üzerindeki etkilerini değerlendirmiştir. Seyrek (2020) çalışmasında Türkiye Deprem Tehlike Haritasını Ege Bölgesi için irdeleyerek, eski ve yeni sismik tehlike haritalarının karşılaştırılmasını Ege Bölgesi için yapmıştır. Öztürk (2018) çalışmasında Türkiye Bina Deprem Yönetmeliği 2018 (TDY 2018) ve Deprem Tehlike Haritalarının eski yönetmelikle karşılaştırılmasını İç Anadolu Bölgesi için yapmıştır. Bozer (2020) çalışmasında Deprem Bölgelerinde Yapılacak Binalar Hakkında Yönetmelik 2007 ve Türkiye Bina Deprem Yönetmeliği 2018'e göre tanımlanan elastik tasarım spektrumlarının kısa periyod ve 1.0s periyod bölgelerinde spektral değerlerini 81 il merkezi için hesaplayarak karşılaştırmıştır. Koçer vd. (2018) çalışmalarında deprem risk düzeyi farklı dört ilin farklı zemin sınıfları için DBYBHY 2007 ve TBDY 2018'de tanımlanan spektral ivme değerleri ile zemin hakim periyodlarını bularak, karşılaştırmıştır. Nemutlu vd. (2020) çalışmalarında DBYBHY 2007 ve TBDY 2018'deki tasarım ivme spektrumlarını Bingöl ve Elazığ il merkezleri için oluşturarak farklı zemin sınıfları için tasarım spektrumları, köşe periyodları ve ivme değerleri arasındaki farkları irdelemiştir. Karaca, Oral ve Erbil (2020) çalışmalarında TBDY 2019 ve DBYBHY 2007'ye göre Niğde ilinde tasarımı yapılmış beş adet bina için sismik tehlike yaklaşımının bina tasarımına olan etkilerini irdelemiştir. Keskin ve Bozdoğan (2018) çalışmalarında Kırklareli ili özelinde DBYBHY 2007 ve TBDY 2018 yönetmeliklerini değerlendirmiştir. Akansel, Sosyal, Kadaş ve Gülkan (2020) çalışmalarında Türkiye Deprem Tehlike Haritaları 2019 ile yürürlükten kalkan 1996 tarihli deprem bölgeleri haritası arasındaki farkı spektral ivme şiddeti ölçütü ile incelemiştir. Özşahin (2021) çalışmasında Türkiye Bina Deprem Yönetmeliği 2019 (TBDY 2019)'a göre Kırklareli ve ilçelerinin deprem yüklerini örnek binalar için hesaplamış, TBDY 2019 ve DBYBHY 2007'ye göre bulduğu eşdeğer deprem yüklerini karşılaştırmıştır. Karasin vd. (2020) çalışmalarında Türkiye'deki yedi farklı coğrafi bölgeden birer il seçerek coğrafi konumun, hem deprem parametrelerine hem de yapı performans hesaplamalarını hangi düzeyde etkilediğini incelemiştir. Sucuoğlu (2019) çalışmasında Türkiye Bina Deprem Yönetme- 
liği 2018'deki yenilik ve gelişmeleri yönetmelik içerindeki sırasına uygun olarak sunmuştur. Sümer ve Hamsici (2020) çalışmalarında TBDY 2018 ile deprem yer hareketi spektrum hesabındaki değişikliğin binaya etki eden deprem kuvveti ve binada oluşan deplasman değerlerindeki değişime etkisini araştırmıştır.

Bu çalışmada önceki çalışmalara katk1 sağlayacak şekilde DBYBYY 2007'ye göre 2., 3. ve 4. deprem bölgesinde olan Edirne merkezi ve 8 ilçesindeki toplam 73 mahalle için binalara etki eden deprem yüklerinin belirlenmesinde kullanılan yatay tasarım ivme spektrumları farklı zemin sınıfları için DBYBHY 2007 ve TBDY 2019 esas alınarak incelenmiştir.

\section{Materyal ve Yöntem}

\subsection{Spektrum Kavramı}

Dinamik analiz yöntemlerinin uzun zaman alan hesaplar gerektirmesi nedeniyle spektral analiz yöntemi günümüzde halen yaygın kullanıma sahiptir. Deprem etkisi altında binanın davranışını belirleyen özellikleri içeren daha genel ve basitleştirilmiş yöntemler uygulamada yaygın olarak kullanılmaktadır (Keskin ve Bozdoğan, 2018). Bu yöntemlerde temel dinamik özellik olarak binanın yanal titreşim periyodları göz önüne alınmakta ve basitleştirme olarak sistem tek serbestlik dereceli sisteme indirgenmekte, deprem süresince oluşan kuvvetler ve yer değiştirmelerin zaman ile değişiminin belirlenmesi yerine bunların en büyük değerleri hesaplanmakta, en büyük etkilere dayanıklı bir binanın daha küçük etkilere de dayanıklı olacağı kabul edilmektedir (Darılmaz, 2018). Tepki spektrumu aynı sönüm oranına, fakat farklı doğal titreşim periyoduna sahip tek serbestlik dereceli sistemlerin belirli bir deprem yer hareketine karşı gösterdiği en büyük yer değiştirme, hız veya ivme tepkilerinin frekans veya periyoda karşı değişimini temsil eden eğrilerdir (Şekil 1) (Darılmaz, 2018; Koçer vd., 2018).

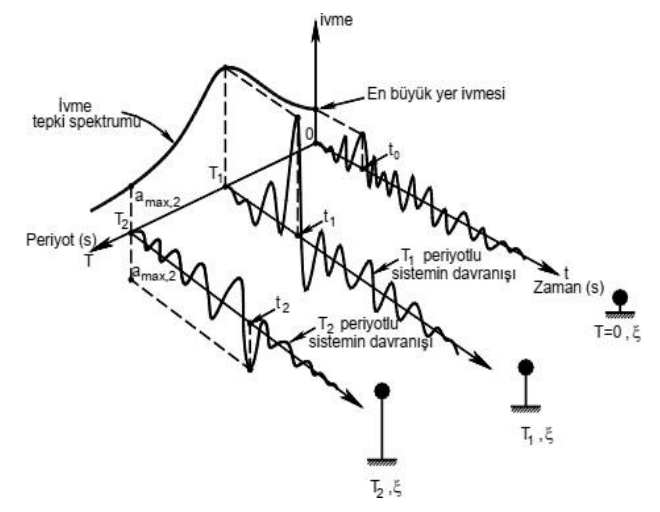

Şekil 1. Tepki spektrumunun grafiksel gösterimi (Darılmaz, 2018)

Tepki spektrumları meydana gelen belirli bir deprem kaydı etkisinde belirli bir sönüm oranı için oluşturulduğu, depremden depreme ve zemin koşullarına göre farklılık gösterdiği için gelecekte oluşacak depremleri ne derece temsil edeceği belirsizdir. Depreme dayanıklı tasarımda genellikle gelecekte meydana gelmesi olası yer hareketlerinin binalar üzerindeki etkilerinin değerlendirilmesi gerekmektedir. Tasarım spektrumları yeni yapıların tasarımında kullanılacak deprem yüklerini belirlemek amacıyla kullanılmaktadır. Binalara etki eden deprem yükünün belirlenmesinde deprem yönetmeliklerinde verilen tasarım spektrum eğrileri kullanılmaktadır (Koçer vd., 2018).

Tasarım spektrumları hazırlanırken incelenen bölgede geçmişte meydana gelmiş depremler göz önüne alınarak, gelecekte meydana gelmesi olası depremlerin belirlenmesi amaçlanmaktadır (Nemutlu vd., 2020). Tasarım spektrumları birçok deprem kaydı kullanılarak bunların sonuçları istatiksel yöntemlerle değerlendirilerek elde edilir, analiz ve boyutlandırma için gerekli karakteristikleri içerir (Darılmaz, 2018; Nemutlu vd., 2020). Deprem hareketinin spektrumu zemin koşullarından önemli derece etkilendiğinden, farklı zemin koşullarına ilişkin spektrum eğrilerinin birbiriyle karşılaştırılabilmesi için normalize edilmesi 
gerekmektedir (Darılmaz, 2018). Deprem yönetmeliklerinde binaların deprem tasarımı için genellikle normalleştirilmiş bir tasarım ivme spektrumu önerilmektedir (Koçer vd., 2018).

\subsection{DBYBHY 2007 ve TBDY 2019 Yönetmeliklerine Göre Yatay İvme Spektrumları}

DBYBHY 2007'de tasarım ivme spektrumlarının belirlenmesinde deprem riskinin bölgesel olarak gösterildiği 1996 tarihli deprem bölgeleri haritası kullanılmıştır. Bu haritada deprem bölgeleri, 50 yılda aşılma olasılığ $\% 10$ ve dönüş periyodu 475 yıl (standart tasarım depremi) olan PGA esas alınarak belirlenmiştir. DBYBHY 2007'de Türkiye, deprem riski açısından beş bölgeye ayrılmıştır (Şahin vd., 2020). DBYBHY 2007 'de \%5 sönüm oranı için tanımlanan elastik ivme spektrumunun ordinatları olan elastik spektral ivme Sae(T), spektral ivme katsayısı A(T) ile yer çekimi ivmesine (g) bağlı olarak (2.1) bağıntısı ile bulunur.

$$
\mathrm{S}_{\mathrm{ae}}(\mathrm{T})=\mathrm{A}(\mathrm{T}) \cdot \mathrm{g}
$$

Spektral ivme katsayısı $\mathrm{A}(\mathrm{T})$ ise etkin yer ivme katsayısı $\left(\mathrm{A}_{0}\right)$, bina önem katsayısı (I) ve spektrum katsayıs1 $\mathrm{S}(\mathrm{T})$ 'ye bağlı olarak (2.2) bağıntısı ile hesaplanmaktadır.

$$
\mathrm{A}(\mathrm{T})=\mathrm{A}_{0} \cdot \mathrm{I} \cdot \mathrm{S}(\mathrm{T})
$$

DBYBHY 2007'de etkin yer ivme katsayısı $\left(\mathrm{A}_{0}\right)$ 1. derece deprem bölgesinden 4. derece deprem bölgesine kadar deprem bölgeleri için sırasıyla 0.4, 0.3, 0.2 ve 0.1 şeklinde verilmiştir. DYBYBHY 2007'de 5. derece deprem bölgesi ise depremselliğin olmadığı bölge olarak tanımlanmıştır.

DBYBHY 2007'de spektrum katsayısı S(T), yerel zemin koşullarına bağlı spektrum karakteristik periyotları $\left(\mathrm{T}_{\mathrm{A}}, \mathrm{T}_{\mathrm{B}}\right.$ ) ve bina doğal periyodu ( $\mathrm{T}$ )'ye bağlı olarak (2.3) bağıntısı ile bulunur.

$$
\mathrm{S}(\mathrm{T})=\left\{\begin{array}{cl}
1+1,5 \frac{\mathrm{T}}{\mathrm{T}_{\mathrm{A}}} & \leftarrow 0 \leq \mathrm{T} \leq \mathrm{T}_{\mathrm{A}} \text { ise } \\
2,5 & \leftarrow \mathrm{T}_{\mathrm{A}}<\mathrm{T} \leq \mathrm{T}_{\mathrm{B}} \text { ise } \\
2,5\left(\frac{\mathrm{T}_{\mathrm{B}}}{\mathrm{T}}\right)^{0,8} & \leftarrow \mathrm{T}_{\mathrm{B}}<\mathrm{T} \text { ise }
\end{array}\right.
$$

(2.3) bağıntısında, elastik tasarım ivme spektrum karakteristik periyotları $T_{A}, T_{B}$ yerel zemin sınıfına göre değişmekle birlikte sabit katsayılardır. DBYBHY 2007 elastik tasarım ivme spektrum eğrisi Şekil 2'de verilmiştir.

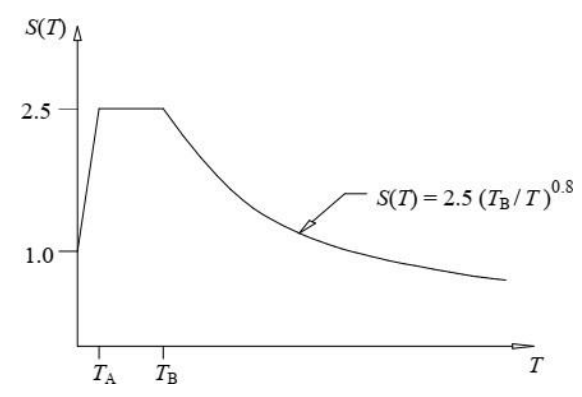

Şekil 2. DBYBHY 2007 elastik tasarım ivme spektrumu

DBYBHY 2007'de en iyi zeminden en kötü zemine doğru zemin özelliklerini ifade eden A, B, C ve D zemin gruplarına ve binanın bulunduğu zemin katmanının kalınlığına göre 4 farklı yerel zemin sınıfı, en iyiden en kötüye doğru Z1, Z2, Z3 ve Z4 olarak tanımlanmıştır. 
Depremde bina taşıyıcı sisteminin doğrusal elastik olmayan davranışını göz önüne almak üzere, spektral ivme katsayısına göre bulunan elastik deprem yükü, deprem yükü azaltma katsayısına $\mathrm{Ra}(\mathrm{T})$ bölünerek azaltılmaktadır. DBYBHY 2007' de deprem yükü azaltma katsayısı Ra(T), taşıyıcı sistem davranış katsayısı (R), binanın doğal titreşim periyodu ( $\mathrm{T}$ ) ve spektrum köşe periyodu $\mathrm{T}_{\mathrm{A}}$ 'ya bağlı olarak (2.4) bağıntısı yardımıyla belirlenmektedir.

$$
\operatorname{Ra}(\mathrm{T})=\left\{\begin{array}{cl}
1,5+(\mathrm{R}-1,5) \frac{\mathrm{T}}{\mathrm{T}_{\mathrm{A}}} & \leftarrow 0 \leq \mathrm{T} \leq \mathrm{T}_{\mathrm{A}} \text { ise } \\
\mathrm{R} & \leftarrow \mathrm{T}_{\mathrm{A}}<\mathrm{T} \text { ise }
\end{array}\right.
$$

TBDY 2019 ve TDTH 2019 ile birlikte deprem bölgeleri kavramı tamamen ortadan kalkmış ve deprem tehlikesi tanımında esaslı değişikliğe gidilmiştir. Binaya etkiyen deprem yüklerinin belirlenmesinde etkili olan TDTH 2019'da deprem riski spektral ivme cinsinden verilmektedir. TBDY 2019'da yatay elastik ivme spektrumunun ordinatları olan yatay elastik tasarım spektral ivmesi $S_{a e}(T)$, tasarım spektral ivme katsayıları ( $S_{D S}$ ve $\left.\mathrm{S}_{\mathrm{D} 1}\right)$ ile bina doğal periyodu $(\mathrm{T})$ ve yatay spektrum köşe periyotlarına $\left(\mathrm{T}_{\mathrm{A}}\right.$ ve $\left.\mathrm{T}_{\mathrm{B}}\right)$ bağlı olarak (2.5) bağıntıs1 ile bulunur.

$$
\mathrm{S}_{\mathrm{ae}}(\mathrm{T})=\left\{\begin{array}{cl}
\left(0,4+0,6 \frac{\mathrm{T}}{\mathrm{T}_{\mathrm{A}}}\right) \mathrm{S}_{\mathrm{DS}} & \leftarrow 0 \leq \mathrm{T} \leq \mathrm{T}_{\mathrm{A}} \text { ise } \\
\mathrm{S}_{\mathrm{DS}} & \leftarrow \mathrm{T}_{\mathrm{A}} \leq \mathrm{T} \leq \mathrm{T}_{\mathrm{B}} \text { ise } \\
\frac{\mathrm{S}_{\mathrm{D} 1}}{\mathrm{~T}} & \leftarrow \mathrm{T}_{\mathrm{B}} \leq \mathrm{T} \leq \mathrm{T}_{\mathrm{L}} \text { ise } \\
\frac{\mathrm{S}_{\mathrm{D} 1} \cdot \mathrm{T}_{\mathrm{L}}}{\mathrm{T}^{2}} & \leftarrow \mathrm{T}_{\mathrm{L}} \leq \mathrm{T} \text { ise }
\end{array}\right.
$$

Tasarım ivme spektrumunun hesabında kullanılan harita spektral ivme katsayıları $\left(\mathrm{S}_{\mathrm{S}}\right.$ ve $\left.\mathrm{S}_{1}\right), \mathrm{T}=0.2 \mathrm{~s}$ ve $\mathrm{T}=1.0 \mathrm{~s}$ periyotlarda referans zemin koşulları dikkate alınan deprem yer hareketi düzeyi (DD) için TDTH'den binanın bulunduğu yerin koordinatlarına bağlı olarak okunmaktadır. Harita spektral ivme katsayıları 50 yılda aşılma olasılığ $\% 2, \% 10, \% 50$ ve \%68 olan dört farklı deprem yer hareketi düzeyi (DD) için elde edilmektedir. TBDY 2019'da söz konusu deprem yer hareketi, en yüksekten en düşük düzeye olmak üzere DD-1, DD-2, DD-3 ve DD-4 olarak tanımlanmaktadır. DBYBHY 2007 'de 50 yılda aşılma olasılığ $\% 10$, tekrarlanma periyodu 475 yıl olan tasarım depreminin TBDY 2019'daki karşılı̆̆ı DD-2'dir.

Harita spektral ivme katsayıları $S_{S}$ ve $S_{1}$, zemin koşullarını yansıtan yerel zemin etki katsayıları $F_{S}$ ve $F_{1}$ ile çarpılarak, tasarım spektral ivme katsayıları $S_{\mathrm{DS}}$ ve $S_{\mathrm{D} 1}$ 'e (2.6) bağıntısı ile dönüştürülmektedir.

$$
\begin{aligned}
& S_{D S}=S_{S} \cdot F_{S} \\
& S_{D 1}=S_{1} \cdot F_{1}
\end{aligned}
$$

TBDY 2019'da yatay spektrum köşe periyodları $T_{A}$ ve $T_{B}$, (2.7) bağıntısı ile belirlenir. Yatay spektrumun sabit yer değiştirme bölgesine geçiş periyodu $T_{L}=6 \mathrm{~s}$ alınmaktadır.

$$
\mathrm{T}_{\mathrm{A}}=0,2 \cdot \frac{\mathrm{S}_{\mathrm{D} 1}}{\mathrm{~S}_{\mathrm{DS}}} ; \quad \mathrm{T}_{\mathrm{B}}=\frac{\mathrm{S}_{\mathrm{D} 1}}{\mathrm{~S}_{\mathrm{DS}}}
$$

TBDY 2019 yatay elastik tasarım ivme spektrum eğrisi Şekil 3’te verilmiştir. 


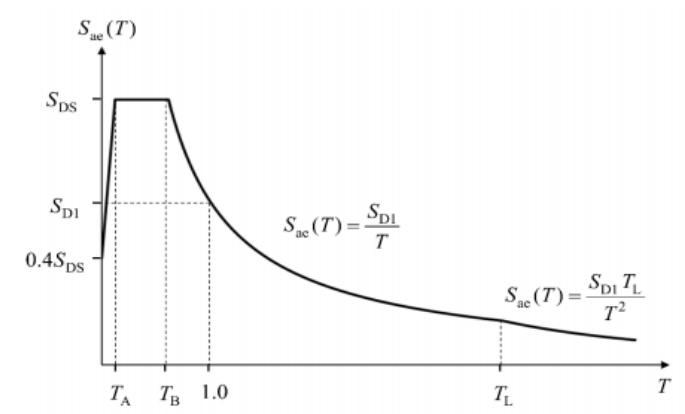

Şekil 3. TBDY 2019 yatay elastik tasarım ivme spektrumu

TBDY 2019'da en iyi zeminden en kötüye doğru ZA, ZB, ZC, ZD, ZE ve ZF olmak üzere 6 farklı yerel zemin sınıfı tanımlanmaktadır. TBDY 2019'da en kötü zemini ifade eden ZF yerel zemin sınıfı, sahaya özel araştırma ve değerlendirme gerektirmektedir.

TBDY 2019'da deprem yükü azaltma katsayısı, taşıyıcı sistem davranış katsayısı (R), dayanım fazlalığı katsayısı (D), bina önem katsayısı (I), binanın doğal titreşim periyodu (T) ve $T_{B}$ spektrum köşe periyoduna bağlı olarak (2.8) bağıntısı ile hesaplanmaktadır.

$$
\operatorname{Ra}(T)=\left\{\begin{array}{cc}
\frac{\mathrm{R}}{\mathrm{I}} & \leftarrow \mathrm{T}>\mathrm{T}_{\mathrm{B}} \text { ise } \\
\mathrm{D}+\left(\frac{\mathrm{R}}{\mathrm{I}}-\mathrm{D}\right) \frac{\mathrm{T}}{\mathrm{T}_{\mathrm{B}}} & \leftarrow \mathrm{T} \leq \mathrm{T}_{\mathrm{B}} \text { ise }
\end{array}\right.
$$

Binaların gerçek dayanımları tasarımda göz önüne alınan dayanımdan fazla olup, söz konusu bu fazlalık binada deprem etkilerine karşı gerektiğinde kullanılabilecek ek bir kapasite oluşturmaktadır. Dayanım fazlalığı katsayısı (D) bu fazlalığın ölçüsünü göstermekte olup, gerçek dayanım ile tasarım dayanımının oranı olarak tanımlanmaktadır (Darılmaz, 2018). TBDY 2019'da tüm bina türleri için taşıyıcı sistem özelliklerine ve süneklik düzeylerine bağlı olarak dayanım fazlalığı katsayıları (D) verilmektedir.

\section{3. Çalışmada İncelenen Bölge}

Çalışma kapsamında incelenen Edirne il merkezi ve ilçelerinin DBYBHY 2007 ve TBDY 2019 yönetmeliklerine göre yatay tasarım ivme spektrumları incelenmiştir (Şekil 4). DBYBHY 2007 ve 1996 tarihli deprem bölgeleri haritasına göre Enez, Keşan ilçeleri 2. derece deprem bölgesinde, İpsala ilçesi 3. derece deprem bölgesinde, Merkez ilçe, Uzunköprü, Süloğlu, Meriç, Lalapaşa ve Havsa ilçeleri ise 4. derece deprem bölgesindedir. Edirne merkezi ve ilçelerindeki toplam 73 mahallenin tasarım ivme spektrumları farklı yerel zemin s1nıfları ve deprem yer hareketi düzeyleri için DBYBHY 2007 ve TBDY 2019'a göre oluşturularak, karşılaştırılmıştır. Edirne merkezi ve ilçelerinin spektral ivme değerleri ve bu değerlere göre zemin hakim periyotları DBYBHY 2007 ve TBDY 2019'a göre belirlenmiş ve karşılaştırılmıştır. Ayrıca DBYBHY 2007'den TBDY 2019'a geçilirken yatay tasarım spektrumlarının Edirne'deki bina stoğunu temsil edebilecek örnek bir betonarme konut binası için eşdeğer deprem kuvvetleri ve tepe yer değiştirmesi üzerindeki değişimi incelenmiştir. 


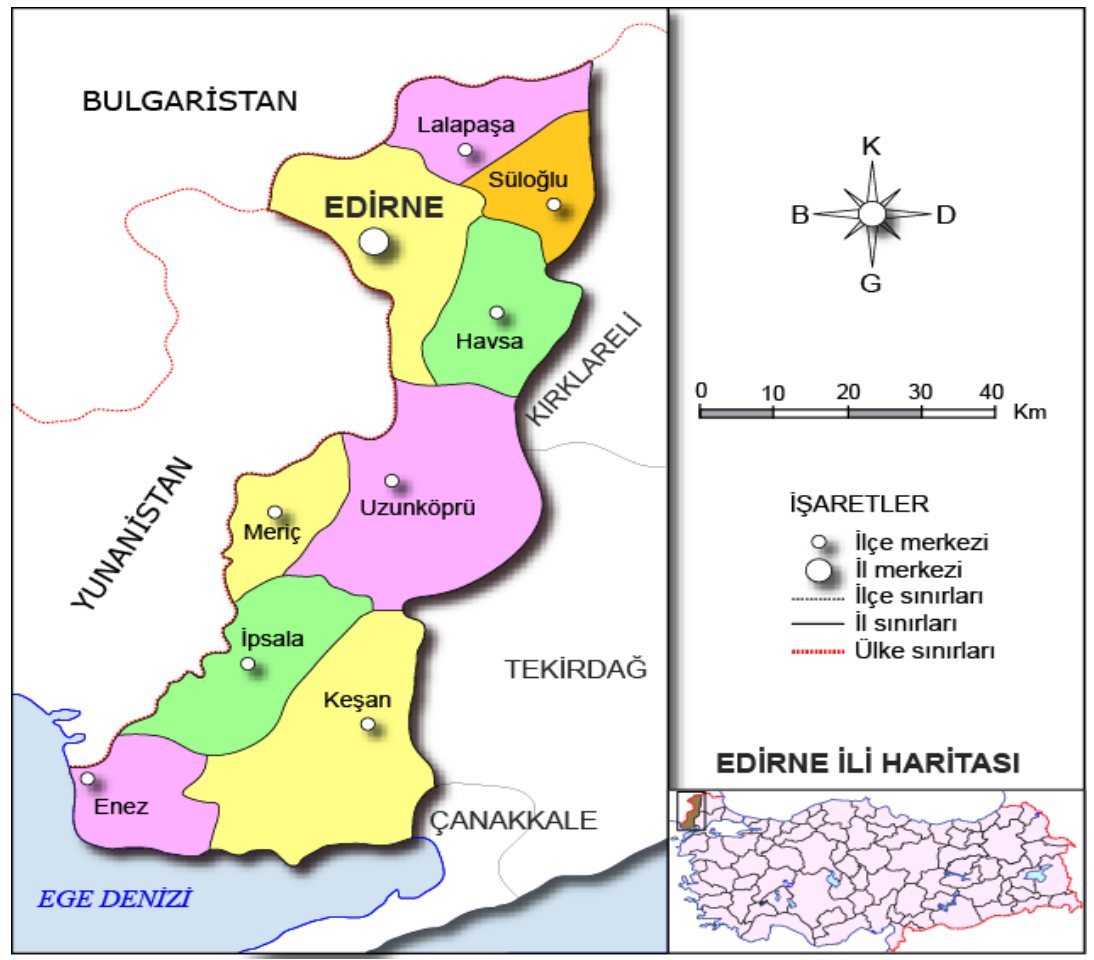

Şekil 4. Edirne ilçeleri haritası (Coğrafya Harita, 2021)

Tasarım ivme spektrumları, spektral ivme değerleri ve zemin hakim periyodları DBYBHY 2007'de tanımlanan Z1, Z2, Z3, Z4 yerel zemin sinıfları, TBDY 2019'da tanımlanan ZA, ZB, ZC, ZD, ZE yerel zemin sinıfları ve DD-1, DD-2, DD-3, DD-4 deprem yer hareketi düzeyleri için ayrı ayrı elde edilmiştir.

TBDY 2019'da verilen yerel zemin sinifları tablosu ile DBYBHY 2007'de verilen zemin grupları ve yerel zemin sınıfları tablosu incelenerek, bu çalışmada yapılan karşılaştırmalarda DBYBHY 2007'deki Z1 yerel sınıfının TBDY 2019' da ZA, ZB yerel zemin sinıflarına, DBYBHY 2007'deki Z2 yerel zemin sınıfının TBDY 2019'da ZC yerel zemin sınıfına, DBYBHY 2007'deki Z3 yerel zemin sınıfinın TBDY 2019'da ZD yerel zemin sınıfına ve DBYBHY 2007'deki Z4 yerel zemin sınıfının TBDY 2019'da ZE yerel zemin sınıfına karş11ık geldiği kabul edilmiştir.

\section{Bulgular ve Tartış̧ma}

\subsection{Edirne Merkezi ve İlçelerinin DBYBHY 2007 ve TBDY 2019'a Göre Yatay Tasarım Spektrumları}

DBYBHY 2007 yönetmeliğine göre spektral ivme değerleri deprem bölgeleri için tanımlanan etkin yer ivme katsayıları $\left(\mathrm{A}_{0}\right)$ kullanılarak belirlenirken, TBDY 2019 yönetmeliğine göre spektral ivme değerleri çalışmada incelenen Edirne merkezi ve ilçelerinin koordinatlarına bağlı olarak TDTH 2019'dan elde edilmiştir. Edirne merkezi ve ilçelerinin TBDY 2019'a göre yatay tasarım spektrum eğrileri yönetmelikte tanımlanan ZA, ZB, ZC, ZD, ZE yerel zemin sınıfı ve DD-1, DD-2, DD-3, DD-4 yer hareketi düzeyi için ayrı ayrı gruplandırılarak çizilmiş̧ir. DBYBHY 2007'ye göre yatay tasarım spektrum eğrileri yönetmelikte tanımlanan Z1, Z2, Z3, Z4 yerel zemin sınıfı ve DD-2 standart deprem yer hareketi düzeyi için çizilmiştir.

Edirne merkezi ve ilçeleri için oluşturulan yatay tasarım spektrum eğrilerinin tamamının verilmesi durumunda çalışmanın sayfa sayısı sınırı aşılacağı için örnek olması açısından Edirne Merkez ve Enez ilçesinin yatay tasarım spektrum eğrileri Şekil 5-6'da verilmiştir. 


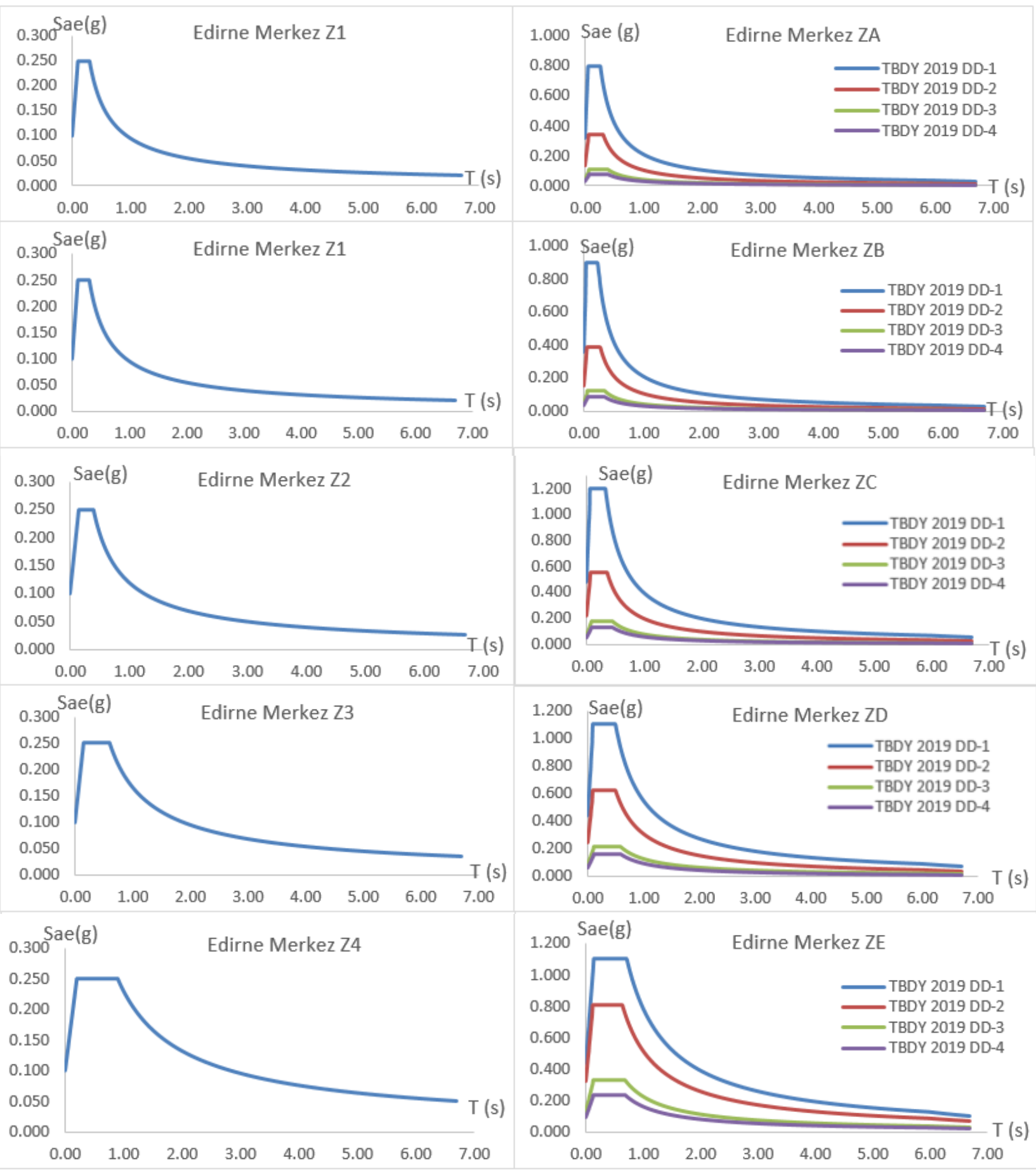

Şekil 5. Edirne merkez ilçesinde farklı zemin sınıfları ve deprem yer hareketi düzeyleri için DBYBHY 2007 ve TBDY 2019'a göre yatay tasarım spektrumları

Şekil 5-6'da Edirne Merkez ve Enez ilçeleri için oluşturulan yatay tasarım ivme spektrumları incelendiğinde, DBYBHY 2007'de ivme spektrumlarının aynı deprem bölgesinde değişiklik göstermediği, TBDY 2019'da ise TDTH 2019'dan okunan ivme parametrelerinin koordinat odaklı olarak değişmesinden dolayı aynı deprem bölgesinde bulunan ilçelerdeki farklı mahallelerde ivme spektrumlarının değiştiği görülmektedir. DBYBHY 2007 'de binaya etki edecek en büyük ivme değeri spektrumda 2.5 iken, TBDY 2019'da en büyük ivme değeri TDTH 2019'dan okunan $S_{D S}$ ile değişen değerler almaktadır. 

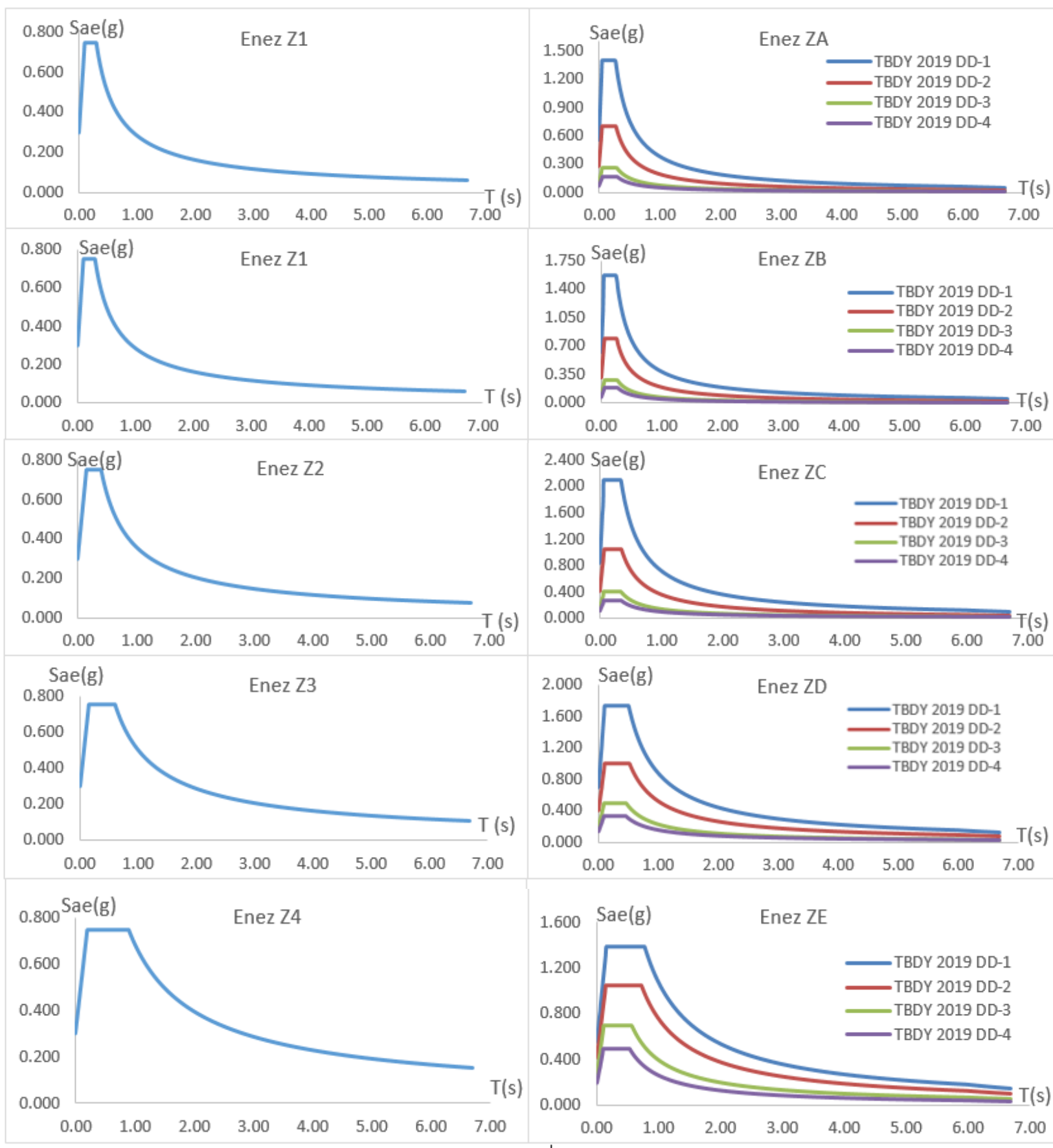

Şekil 6. Enez ilçesinin farklı zemin sınıfları ve deprem yer hareketi düzeyleri için DBYBHY 2007 ve TBDY 2019'a göre yatay tasarım spektrumları

DBYBHY 2007'de binanın bulunduğu deprem bölgesine göre etkin yer ivme katsayısı ( $\left.\mathrm{A}_{0}\right)$ ile tasarım spektrumu ordinatları düşey yönde ölçeklendirilirken, TBDY 2019'da bu hesap $\mathrm{S}_{\mathrm{S}}$ ve $\mathrm{S}_{1}$ spektral ordinatları ile yapılmaktadır. DBYBHY 2007'de ivme spektrumları tek bir spektrum eğrisi ile ifade edilirken, TBDY 2019'da aynı yerel zemin sınıfında yönetmelikte tanımlanan deprem yer hareketi düzeyleri için 4 farklı spektrum eğrisi ile ifade edilmektedir. TBDY 2019 spektrum eğrileri, deprem yer hareketi düzeylerine göre değişmektedir. TBDY 2019'da tanımlanan deprem yer hareketi düzeylerine göre en büyük ivme değerleri DD-1'de görülür iken, en küçük ivme değerleri DD-4'de görülmektedir (Nemutlu vd., 2020). DBYBHY 2007'de en büyük tasarım spektral ivmesi aynı deprem bölgesinde bütün zemin sınıfları için aynı olup, bina periyodunun 
belirli bir değerden az olması durumunda bütün binalar tüm zemin koşulları için aynı tasarım ivmesi ile yüklenmektedir. TBDY 2019 tasarım spektrumunun tepe değeri olan kısa periyot spektral ivmeleri $\left(\mathrm{S}_{\mathrm{DS}}\right)$ binanın konumuna göre değişmekte, binalar farklı tasarım ivmesi ile yüklenmektedir. Bu sebeple bina tasarımında TBDY 2019 spektral ivmelerinin kullanılması durumunda DBYHBHY 2007'ye göre daha gerçekçi sonuçlar elde edilmektedir.

\subsection{Edirne Merkezi ve İlçelerinin DBYBHY 2007 ve TBDY 2019'a Göre Yatay Tasarım Spektrumla- rının Karşılaştırılması}

TBDY 2019 ve DBYBHY 2007 yönetmeliklerine göre yatay tasarım spektrum eğrilerinin karşılaştırılması için oluşturulan grafiklerin tamamının verilmesi durumunda çalışma sayfa sayısı sınırı aşılacağı için örnek olması açısından Edirne Merkez, Enez ve İpsala ilçeleri için spektrum eğrileri Şekil 7, 8, 9'da verilmiştir. Spektrum eğrilerinin karşılaştırılması, DBYBHY 2007'de tanımlanan standart tasarım depremi yer hareketi düzeyi ve standart tasarım depreminin TBDY 2019'daki karşılığg olan DD-2 deprem yer hareketi düzeyi için yapılmıştır. TBDY 2019 ve DBYBHY 2007'ye göre yatay tasarım spektrum eğrilerinin karşılaştırılmasında TBDY 2019'da tanımlanan ZA, ZB, ZC, ZD ve ZE yerel zemin sınıflarının DBYBHY 2007'deki karş1lığ1 sırasıyla Z1, Z1, Z2, Z3 ve Z4 olarak kabul edilmiştir.

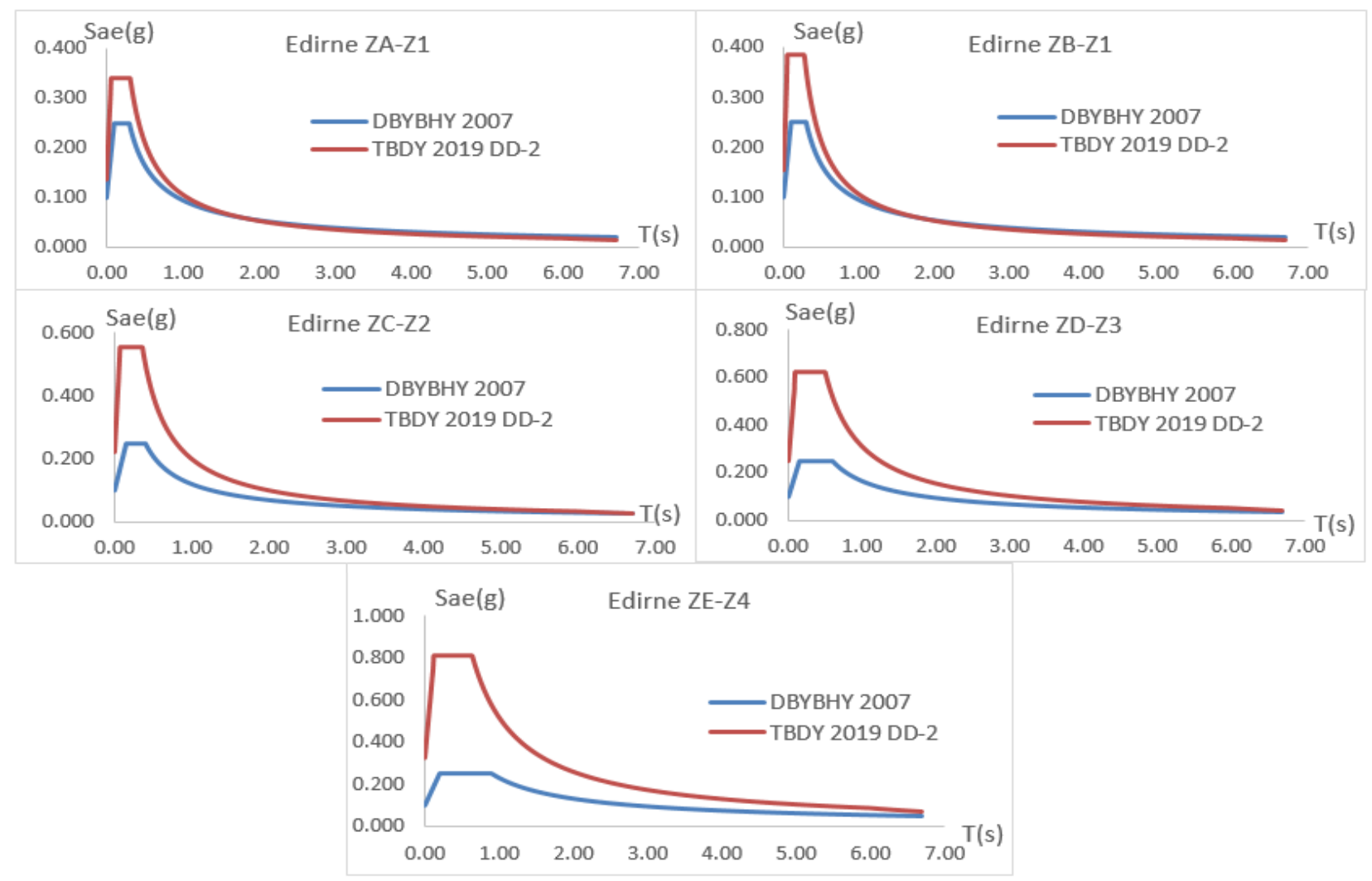

Şekil 7. Edirne merkez ilçesinin DD-2 deprem yer hareket düzeyi ve farklı yerel zemin sınıfları için DBYBHY 2007 ve TBDY 2019 yatay tasarım spektrumlarının karşılaştııılması

Edirne merkez ilçesinin TBDY 2019 DD-2 deprem yer hareketi düzeyi için oluşturulan, Şekil 7'de verilen yatay tasarım spektrum eğrileri incelendiğinde, TBDY 2019'a göre belirlenen spektral ivme değerlerinin tüm zemin sınıfları için DBYBHY 2007 spektral ivme değerlerinden büyük olduğu görülmektedir. Yerel zemin sınıfları ZA'dan ZE'ye doğru gittikçe TBDY 2019'a göre belirlenen spektral ivme değerleri büyümekte ve DBYBHY 2007'ye göre belirlenen spektral ivme değerleri ile arasındaki farklar artmaktadır. ZA-Z1 ve ZBZ1 yerel zemin sınıflarında T=1.50s'den büyük periyotlar için DBYBHY 2007 ile TBDY 2019 spektral ivme değerleri birbirine çok yakın değerler almakta, yatay spektrum eğrileri bu bölgede çakışmaktadır. 


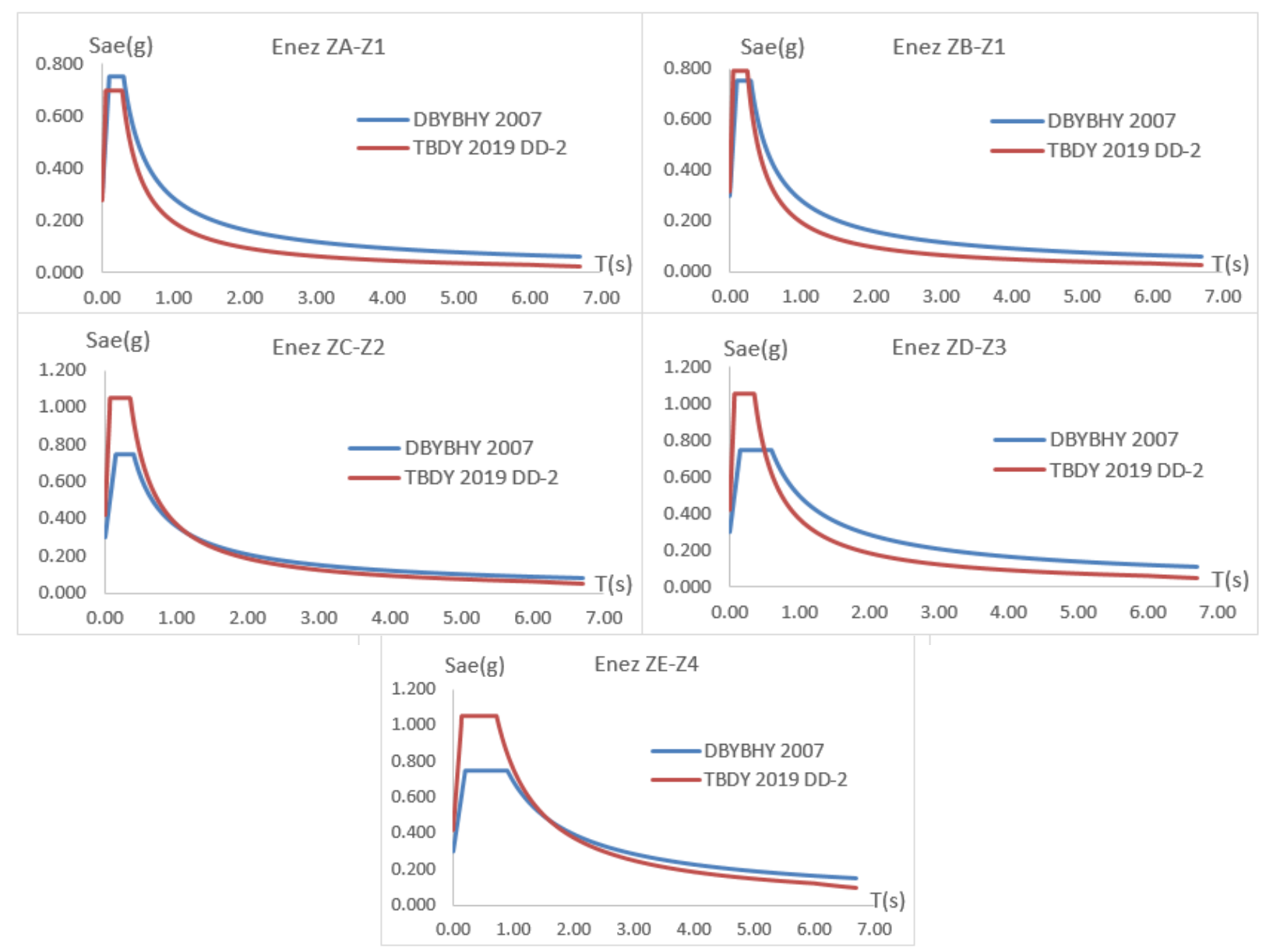

Şekil 8. Enez ilçesinin DD-2 deprem yer hareketi düzeyi ve farklı yerel zemin sınıfları için DBYBHY 2007 ve TBDY 2019 yatay tasarım spektrumlarının karşılaştırılması

Enez ilçesinin TBDY 2019 DD-2 deprem yer hareketi düzeyi için oluşturulan, Şekil 8'de verilen yatay tasarım spektrum eğrileri incelendiğinde, ZA-Z1 yerel zemin sınıfında DBYBHY 2007'nin spektral ivme değerlerinin TBDY 2019 spektral ivme değerlerinden büyük olduğu görülmektedir. Diğer zemin sınıflarında T=0.30 s'den daha küçük periyotlar için TBDY 2019 spektral ivme değerlerinin, DBYBHY 2007 spektral ivme değerlerinden büyük, 0.30 s'den büyük periyotlar için ise küçük olduğu görülmektedir. Zemin sınıfları ZB'den ZE'ye doğru gittikçe, TBDY 2019 ve DBYBHY 2007 spektral ivme değerleri arasındaki farklar artmaktadır.

Havsa ilçesinin TBDY 2019 DD-2 deprem yer hareketi düzeyi için oluşturulan yatay tasarım spektrum eğrileri incelendiğinde, TBDY 2019'a göre belirlenen spektral ivme değerlerinin tüm zemin sinıfları için DBYBHY 2007 spektral ivme değerlerinden büyük olduğu görülmektedir. Zemin sınıfları ZA'dan ZE'ye doğru gittikçe TBDY 2019 spektral ivme değerlerinde DBYBHY 2007'ye göre artış görülmekte ve spektral ivme değerleri arasındaki fark artarak, daha belirgin olmaktadır. ZA-Z1 ve ZB-Z1 zemin sınıflarında $\mathrm{T}=1.90$ s'den büyük periyotlar için DBYBHY 2007 ve TBDY 2019 spektral ivme değerleri birbirine çok yakın değerler almakta, yatay spektrum eğrileri bu bölgede çakışmaktadır. 


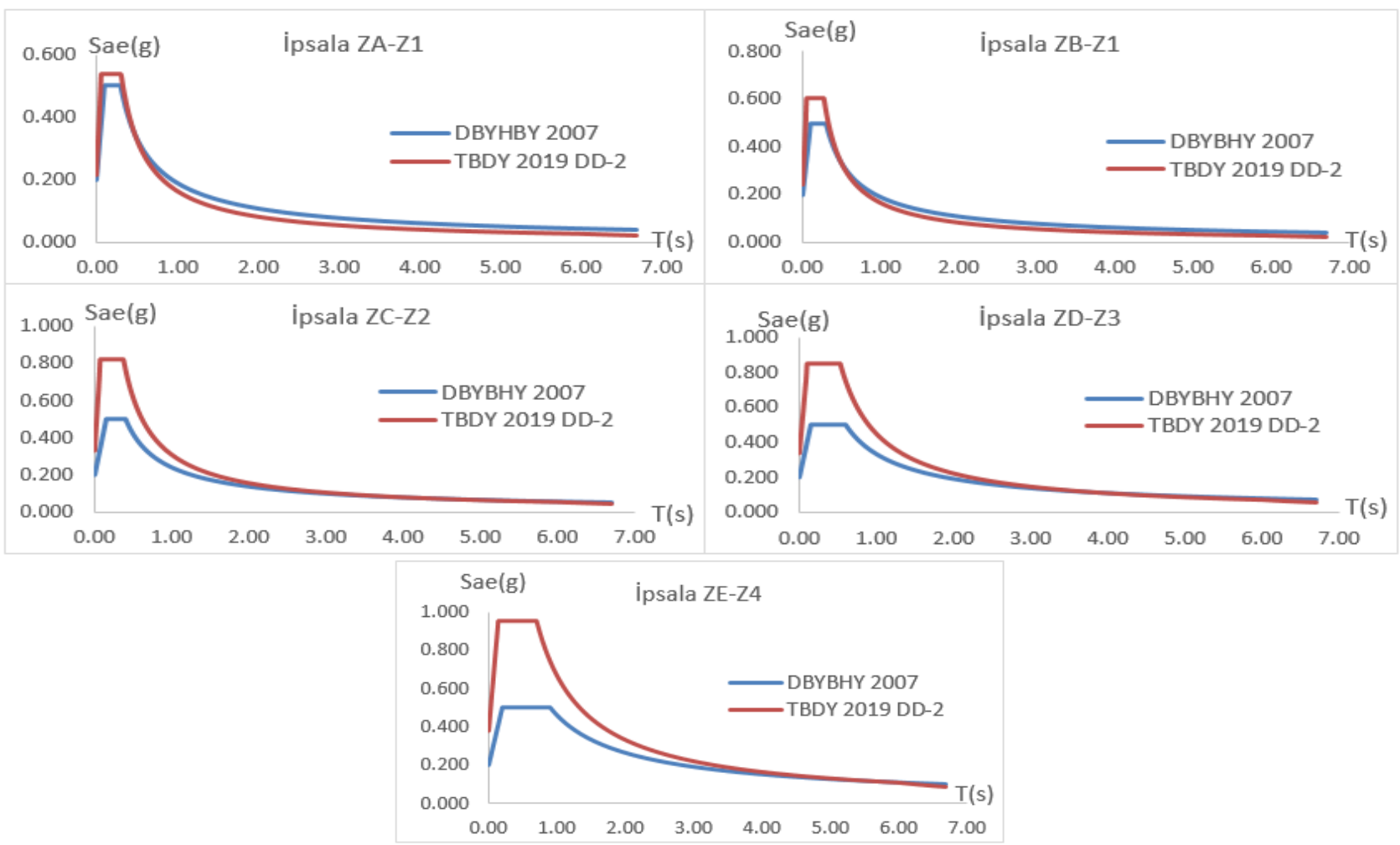

Şekil 9. İpsala ilçesinin DD-2 deprem yer hareketi düzeyi ve farklı yerel zemin sınıfları için DBYBHY 2007 ve TBDY 2019 yatay tasarım spektrumlarının karşılaştırılması

İpsala ilçesinin TBDY 2019 DD-2 deprem yer hareketi düzeyi için oluşturulan, Şekil 9'da verilen yatay tasarım spektrum eğrileri incelendiğinde, ZA-Z1 ve ZB-Z1 zemin sınıflarında $\mathrm{T}=0.50 \mathrm{~s}$ 'den daha küçük periyot değerleri için TBDY 2019 spektral ivme değerlerinin DBYBHY 2007 spektral ivme değerlerinden büyük olduğu, T=0.50s'den büyük periyotlar için TBDY 2019 spektral ivme değerlerinin DBYBHY 2007 spektral ivme değerlerinden küçük olduğu görülmektedir. Diğer zemin sınıflarında $\mathrm{T}=3.0 \mathrm{~s}$ 'den büyük periyotlar için DBYBHY 2007 ve TBDY 2019 spektral ivme değerleri birbirine eşit değerler almakta, bu bölgede yatay spektrum eğrileri çakışmaktadır.

Keşan ilçesinin TBDY 2019 DD-2 deprem yer hareketi düzeyi için oluşturulan yatay tasarım spektrum eğrileri incelediğinde ZA-Z1 ve ZB-Z1 zemin sınıflarında DBYBHY 2007 spektral ivme değerlerinin TBDY 2019 spektral ivme değerlerinden büyük olduğu görülmektedir. Diğer zemin sınıflarında $T=1.0 \mathrm{~s}$ 'den daha küçük periyotlar için TBDY 2019 spektral ivme değerlerinin TBDY 2019 spektral ivme değerlerinden büyük, T=1.0s'den büyük periyotlar için TBDY 2019 spektral ivme değerleri DBYBHY 2007 spektral ivme değerlerinden küçüktür. Zemin sınıfları ZC'den ZE'ye doğru gittikçe, DBYBHY 2007 ve TBDY 2019 spektral ivme değerleri arasındaki farklar artarak, daha belirginleşmektedir.

Lalapaşa, Meriç, Süloğlu ve Uzunköprü ilçelerinin TBDY 2019 DD-2 deprem yer hareketi düzeyi için oluşturulan yatay spektrum eğrileri incelendiğinde TBDY 2019 spektral ivme değerlerinin neredeyse tüm zemin sınıfları için DBYBHY 2007 spektral ivme değerlerinden büyük olduğu görülmektedir. Zemin sınıfları ZA'dan ZE'ye doğru gittikçe, TBDY 2019'a göre belirlenen spektral ivme değerleri büyümekte ve DBYBHY 2007'ye göre belirlenen spektral ivme değerleri ile arasındaki farklar artmaktadır. ZA-Z1 ve ZB-Z1 yerel zemin sınıflarında T=1.0s'den büyük periyot değerleri için DBYBHY 2007 ve TBDY 2019 spektral ivme değerleri birbirine çok yakın değerler almakta, yatay spektrum eğrileri bu bölgede çakışmaktadır.

Çalışma kapsamında incelenen Edirne merkezi ve ilçelerindeki mahallelerin etkin yer ivme katsayıları $\left(\mathrm{A}_{0}\right)$ DBYBHY 2007'den alınırken, TBDY 2018 için en büyük yer ivmesi (PGA) ilçelerdeki mahallelerin konumlarına bağlı olarak TDTH'dan okunmuştur. Edirne merkez ve ilçelerinin standart tasarım depremi (DD-2) için 
DBYBHY 2007 deprem bölgeleri için etkin yer ivme katsayıları $\left(\mathrm{A}_{0}\right)$ ile TDTH'dan okunan en büyük yer ivmesi değerlerinin (PGA) en küçük, en büyük ve ortalama değerlerinin karşılaştırması Tablo 1'de verilmiştir.

Tablo 1

DBYBHY 2007 ve TBDY 2019'a göre DD-2 tasarım depremi için Edirne merkez ve ilçelerinin PGA değerleri

\begin{tabular}{|c|c|c|c|c|c|c|c|c|}
\hline \multirow{2}{*}{$\begin{array}{l}\text { Yerleşim } \\
\text { Yeri }\end{array}$} & \multirow{2}{*}{$\begin{array}{c}\text { DBYBHY } \\
2007 \\
\text { Deprem } \\
\text { Bölgesi }\end{array}$} & \multirow{2}{*}{$\begin{array}{c}\text { DBYBHY } \\
\text { 2007 } \\
\text { PGA } \\
\text { (g) }\end{array}$} & \multicolumn{4}{|c|}{ TBDY 2019 PGA (g) } & \multicolumn{2}{|c|}{$\mathbf{P G A}_{2019} / \mathbf{P G A}_{2007}$} \\
\hline & & & $\begin{array}{c}\text { En } \\
\text { Küçük }\end{array}$ & Ortalama & $\begin{array}{c}\text { En } \\
\text { Büyük }\end{array}$ & $\begin{array}{c}\text { En } \\
\text { Küçük }\end{array}$ & Ortalama & $\begin{array}{c}\text { En } \\
\text { Büyük }\end{array}$ \\
\hline $\begin{array}{l}\text { Edirne } \\
\text { Merkez }\end{array}$ & 4 & 0.10 & 0.180 & 0.181 & 0.184 & 1.80 & 1.81 & 1.82 \\
\hline Enez & 2 & 0.30 & 0.355 & 0.363 & 0.372 & 1.18 & 1.21 & 1.24 \\
\hline Havsa & 4 & 0.10 & 0.173 & 0.174 & 0.174 & 1.73 & 1.74 & 1.74 \\
\hline İpsala & 3 & 0.20 & 0.277 & 0.280 & 0.283 & 1.39 & 1.40 & 1.42 \\
\hline Keşan & 2 & 0.30 & 0.274 & 0.310 & 0.333 & 0.91 & 1.03 & 1.11 \\
\hline Lalapaşa & 4 & 0.10 & 0.167 & 0.168 & 0.169 & 1.67 & 1.68 & 1.69 \\
\hline Meriç & 4 & 0.10 & 0.196 & 0.197 & 0.198 & 1.96 & 1.97 & 1.98 \\
\hline Süloğlu & 4 & 0.10 & 0.166 & 0.166 & 0.167 & 1.66 & 1.66 & 1.67 \\
\hline Uzunköprü & 4 & 0.10 & 0.185 & 0.194 & 0.217 & 1.85 & 1.94 & 2.17 \\
\hline
\end{tabular}

Tablo 1 incelendiğinde Edirne merkezi ve ilçelerinin tamamında TBDY 2019'a göre elde edilen en büyük yer ivme değerlerinin (PGA), DBYBHY 2007'ye göre büyük olduğu görülmektedir. TBDY 2019 ivme değerlerinin DBYBHY 2007'ye göre, DBBHY 2007'de 4. derece deprem bölgesinde olan ilçelerde ortalama 1.66-1.94 kat, 3. derece deprem bölgesinde olan ilçede ortalama 1.40 kat ve 2 . derece deprem bölgesinde olan ilçelerde ortalama 1.03-1.21 kat arttığı görülmektedir. Çalışma kapsamında incelenen bölgede ivme oranlarındaki en büyük artışın DBYBHY 2007'ye göre 4. derece deprem bölgesinde olan ilçelerdeki mahallelerde olduğu, DBYBHY 2007'ye göre deprem riskinin daha fazla olduğu 3. ve 2. derece deprem bölgelerindeki mahallelerde ise ivme oranlarındaki artışın daha az olduğu gözlenmiştir.

Edirne merkezi ve ilçelerinin DD-2 deprem yer hareketi düzeyi için yatay tasarım spektrumu köşe periyotlar1nın DBYBHY 2007 ve TBDY 2019'a göre değişimi Tablo 2'de verilmiştir.

Tablo 2

DBBYBHY 2007 ve TBDY 2019'a göre DD-2 tasarım depremi için Edirne merkez ve ilçelerinin zemin hakim periyotlar1

\begin{tabular}{|c|c|c|c|c|c|c|c|c|c|c|c|c|c|c|c|c|c|c|}
\hline \multirow{3}{*}{$\begin{array}{l}\text { Yerleşim } \\
\text { Yeri }\end{array}$} & \multicolumn{9}{|c|}{ DBYBHY 2007} & \multicolumn{9}{|c|}{ TBDY 2019} \\
\hline & \multicolumn{2}{|c|}{$\mathbf{Z 1}$} & \multicolumn{2}{|c|}{$\mathbf{Z 2}$} & \multicolumn{2}{|c|}{$\mathrm{Z3}$} & \multicolumn{2}{|c|}{$\mathbf{Z 4}$} & \multicolumn{2}{|c|}{$\mathbf{Z A}$} & \multicolumn{2}{|c|}{ ZB } & \multicolumn{2}{|c|}{$\mathrm{ZC}$} & \multicolumn{2}{|c|}{ ZD } & \multicolumn{2}{|c|}{ ZE } \\
\hline & TA & TB & TA & TB & TA & TB & TA & TB & TA & TB & TA & TB & TA & TB & TA & TB & TA & TB \\
\hline $\begin{array}{l}\text { Edirne } \\
\text { Merkez }\end{array}$ & & & & & & & & & 0.06 & 0.31 & 0.06 & 0.28 & 0.07 & 0.36 & 0.10 & 0.50 & 0.13 & 0.64 \\
\hline Enez & & & & & & & & & 0.06 & 0.29 & 0.05 & 0.25 & 0.07 & 0.36 & 0.10 & 0.52 & 0.15 & 0.73 \\
\hline Havsa & & & & & & & & & 0.07 & 0.34 & 0.06 & 0.30 & 0.08 & 0.39 & 0.11 & 0.53 & 0.13 & 0.64 \\
\hline İpsala & & & & & & & & & 0.06 & 0.31 & 0.05 & 0.27 & 0.08 & 0.37 & 0.11 & 0.53 & 0.14 & 0.70 \\
\hline Keşan & 0.10 & 0.30 & 0.15 & 0.40 & 0.15 & 0.60 & 0.20 & 0.90 & 0.06 & 0.30 & 0.05 & 0.27 & 0.08 & 0.38 & 0.11 & 0.54 & 0.15 & 0.73 \\
\hline Lalapaşa & & & & & & & & & 0.06 & 0.31 & 0.06 & 0.28 & 0.07 & 0.36 & 0.10 & 0.49 & 0.13 & 0.62 \\
\hline Meriç & & & & & & & & & 0.07 & 0.34 & 0.06 & 0.30 & 0.08 & 0.39 & 0.11 & 0.55 & 0.14 & 0.70 \\
\hline Süloğlu & & & & & & & & & 0.06 & 0.32 & 0.06 & 0.29 & 0.07 & 0.37 & 0.10 & 0.51 & 0.13 & 0.64 \\
\hline Uzunköprü & & & & & & & & & 0.07 & 0.34 & 0.06 & 0.30 & 0.08 & 0.40 & 0.11 & 0.55 & 0.14 & 0.69 \\
\hline
\end{tabular}

Edirne merkezi ve ilçelerinin köşe periyotları, DBYBHY 2007'ye göre farklı deprem bölgesinde olan aynı zemin sınıfları için aynı değerler almaktadır. TBDY 2019'a göre Edirne merkezi ve ilçelerinin benzer zemin koşullarında köşe periyotları $S_{D S}$ ve $S_{D 1}$ 'e bağlı olduğu için farklı değerler almaktadır. DBYBHY 2007'de köşe 
periyotları bölgesel olarak değişmezken, TBDY 2019'da köşe periyotları bölgesel olarak değişmekte, farklı değerler almaktadır. DBYBHY 2007'de köşe periyotları $\mathrm{T}_{\mathrm{A}}$ ve $\mathrm{T}_{\mathrm{B}}$, yerel zemin sınıfına bağlı katsayılar iken TBDY 2019'da $T_{A}$ ve $T_{B}$ köşe periyotları binanın bulunduğu yerin konumuna bağlı olarak TDTH'dan okunan $S_{D S}$ ve $S_{D 1}$ spektral ivme değerlerine bağlı olarak değişmektedir.

Edirne merkezi ve ilçeleri için TBDY 2019 yönetmeliğine göre yatay tasarım spektrumlarının oluşturulmasında kullanılan koordinata bağlı parametreler olan $S_{D S}$ ve $S_{D 1}$ değerleri ve bu değerlerinin DBYBHY 2007 yönetmeliğindeki karşıllkları Tablo 3 ve Tablo 4'te verilmiştir.

Tablo 3

TBDY 2019'a göre DD-2 tasarım depremi için Edirne merkez ve ilçelerinin spektral ivme katsayıları

\begin{tabular}{lcccccccccc}
\hline \multicolumn{1}{c}{$\begin{array}{c}\text { Yerleşim } \\
\text { Yeri }\end{array}$} & \multicolumn{2}{c}{ ZA } & \multicolumn{2}{c}{ ZB } & \multicolumn{2}{c}{ ZC } & \multicolumn{2}{c}{ ZD } & \multicolumn{3}{c}{ ZE } \\
\cline { 2 - 11 } \\
$\begin{array}{l}\text { Edirne } \\
\text { Merkez }\end{array}$ & 0.341 & 0.106 & 0.384 & 0.106 & 0.554 & 0.199 & 0.622 & 0.309 & 0.813 & 0.518 \\
\hline Enez & 0.702 & 0.201 & 0.789 & 0.201 & 1.053 & 0.375 & 1.008 & 0.525 & 1.051 & 0.763 \\
\hline Havsa & 0.327 & 0.110 & 0.368 & 0.110 & 0.532 & 0.206 & 0.602 & 0.320 & 0.800 & 0.496 \\
\hline İpsala & 0.536 & 0.164 & 0.603 & 0.164 & 0.825 & 0.308 & 0.847 & 0.449 & 0.957 & 0.671 \\
\hline Keşan & 0.599 & 0.182 & 0.674 & 0.182 & 0.902 & 0.341 & 0.902 & 0.488 & 0.980 & 0.719 \\
\hline Lalapaşa & 0.316 & 0.098 & 0.356 & 0.098 & 0.513 & 0.185 & 0.586 & 0.290 & 0.788 & 0.491 \\
\hline Meriç & 0.374 & 0.127 & 0.420 & 0.127 & 0.607 & 0.238 & 0.666 & 0.363 & 0.837 & 0.583 \\
\hline Süloğlu & 0.311 & 0.101 & 0.352 & 0.101 & 0.508 & 0.189 & 0.581 & 0.296 & 0.784 & 0.499 \\
\hline Uzunköprü & 0.366 & 0.125 & 0.412 & 0.125 & 0.594 & 0.235 & 0.656 & 0.358 & 0.832 & 0.578 \\
\hline
\end{tabular}

Tablo 4

DBYBHY 2007'ye göre DD-2 tasarım depremi için Edirne merkez ve ilçelerinin spektral ivme katsayıları

\begin{tabular}{lccccc}
\hline \multirow{2}{*}{ Yerleşim Yeri } & Z1-Z2-Z3-Z4 & $\mathbf{Z 1}$ & $\mathbf{Z 2}$ & $\mathbf{Z 3}$ & $\mathbf{Z 4}$ \\
\cline { 2 - 6 } & SDs & SD1 & SD1 & SD1 & SD1 \\
\hline Edirne Merkez & 0.25 & 0.095 & 0.120 & 0.166 & 0.230 \\
\hline Enez & 0.75 & 0.286 & 0.360 & 0.498 & 0.698 \\
\hline Havsa & 0.25 & 0.095 & 0.120 & 0.166 & 0.230 \\
\hline İpsala & 0.50 & 0.191 & 0.240 & 0.332 & 0.460 \\
\hline Keşan & 0.75 & 0.286 & 0.360 & 0.498 & 0.698 \\
\hline Lalapaşa & 0.25 & 0.095 & 0.120 & 0.166 & 0.230 \\
\hline Meriç & 0.25 & 0.095 & 0.120 & 0.166 & 0.230 \\
\hline Süloğlu & 0.25 & 0.095 & 0.120 & 0.166 & 0.230 \\
\hline Uzunköprü & 0.25 & 0.095 & 0.120 & 0.166 & 0.230
\end{tabular}

Tablo 3 incelendiğinde Enez ilçesi dışında tüm ilçelerde ZA zemin sınıfindan ZE zemin sınıfina doğru $\mathrm{S}_{\mathrm{DS}}$ değerlerinde artış meydana gelmektedir. Enez ilçesinde ise ZA zemin sınıfında ZC zemin sınıfına doğru gidildikçe $S_{D S}$ değerleri artarken, $Z C$ zemin sınıfından ZE zemin sınıfına doğru gidildikçe $S_{D S}$ değerleri azalmaktadır. Edirne merkezi ve ilçelerinin tamamında $\mathrm{S}_{\mathrm{D} 1}$ değerleri, ZA zemin sınıfından ZE zemin sınıfına doğru gidildikçe artmaktadır. Bunun sebebi, TBDY 2019'da zemin koşullarını yansıtan yerel etki katsayılarının Fs ve $F_{1}$, spektral ivme katsayıları $S s$ ve $S_{1}$ 'in değerine göre farklı zemin sınıfları için değişmesidir. Örneğin Enez ilçesinde TDTH'dan okunan Ss=0.877 değeri için kısa periyot yerel zemin etki katsayısı Fs, ZA zemin sınıfindan ZC zemin sinıfina kadar artarken, ZC zemin sinıfından ZE zemin sinıfina kadar azalmakta ve $S_{1}=0.250$ değeri için $1.0 \mathrm{~s}$ periyot yerel etki katsayısı $\mathrm{F}_{1}$, ZA zemin sınıfından $\mathrm{ZE}$ zemin sınıfına kadar artmaktadır. Tablo 4'ten görüldüğü üzere DBYBHY 2007'de tasarım spektral ivme katsayısı, $S_{D S}$, aynı deprem bölgesinde farklı

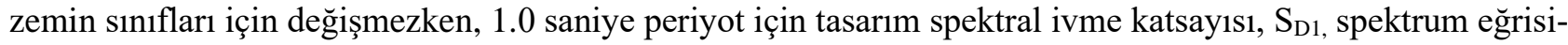
nin azalan bölgesinde kaldığı için zemin sınıflarından etkilenmekte ve farklı değerler almaktadır. Tablo 3-4 ile 
Şekil 5-9'dan görüldügü üzere DBYBHY 2007'de $T_{A}$ ve $T_{B}$ spektrum köşe periyotları zemin koşullarına göre değişse de tasarım spektrumunun sadece azalan bölgesi zemin koşullarından etkilenmektedir. TBDY 2019'da ise $T_{A}$ ve $T_{B}$ spektrum köşe periyotları zemin koşullarına göre değişmekte ve tasarım spektrumunun tüm bölgeleri (ivme, hız, deplasman) zemin koşullarından etkilenmekte yerel zemin sınıfına göre düzeltilmiş $\mathrm{S}_{\mathrm{DS}}$ ve $\mathrm{S}_{\mathrm{D} 1}$ spektral ordinatlarına göre spektrum eğrisindeki platonun uzunluğu değişmektedir.

DBYBHY 2007'ye göre 4. derece deprem bölgesinde bulunan Edirne Merkez, Havsa, Lalapaşa, Meriç, Uzunköprü ilçelerinin TBDY 2019 spektral ivme katsayısı ( $\left.\mathrm{S}_{\mathrm{DS}}\right)$ değeri ZE zemin sınıfında en yüksek değerine ulaşmakta, DBYBHY 2007 spektral ivme katsayısı $\left(\mathrm{S}_{\mathrm{DS}}\right)$ değerine göre yaklaşık Edirne Merkez ilçede \%225, Havsa ilçesinde \%220, Lalapaşa ilçesinde \%220, Lalapaşa ilçesinde \%215, Meriç ilçesinde \%235, Süloğlu ilçesinde \%214 ve Uzunköprü ilçesinde \%233 artmaktadır. DBYBHY 2007'ye göre 3. derece deprem bölgesinde bulunan İpsala ilçesinin TBDY 2019 spektral ivme katsayısı ( $\mathrm{S}_{\mathrm{DS}}$ ) değeri ZE zemin sınıfinda en yüksek değerine ulaşmakta, DBYBHY 2007 spektral ivme katsayısı $\left(\mathrm{S}_{\mathrm{DS}}\right)$ değerine göre yaklaşı \%91 artmaktadır. DBYBHY 2007'ye göre 2. derece deprem bölgesinde bulunan Enez ilçesinin TBDY 2019 spektral ivme katsayısı $\left(\mathrm{S}_{\mathrm{DS}}\right)$ değeri ZC zemin sınıfında en yüksek değerine ulaşırken, Keşan ilçesinde ZE zemin sınıfında ulaşmakta ve DBYBHY 2007 spektral ivme katsayısı $\left(\mathrm{S}_{\mathrm{DS}}\right)$ değerine göre yaklaşık Enez ilçesinde \%40, Keşan ilçesinde \%31 artmaktadır.

\subsection{Edirne Merkezi ve İlçelerinin DBYBHY 2007 ve TBDY 2019 Yatay Tasarım Spektrumlarının Ör- nek Bir Betonarme için Taban Kesme Kuvveti ve Tepe Yer Değiştirmesi Üzerindeki Değişimleri}

TBDY 2019 ve DBYBHY 2007'de tanımlanan betonarme çerçeve sistem için Edirne ilindeki konut stoğunu temsil edebilecek örnek bir bina modelinin hesaplanan eşdeğer deprem yükleri ve tepe yer değiştirmeleri değerlendirilmiştir. Örnek bina modellerinin tasarımı ve yapısal hesapları TS500, DBYBHY 2007 ve TBDY 2019 yönetmelikleri için Sta4Cad V.14.1 programı ile yapılmıştır. Çalışma kapsamında incelenen örnek bina modelinin kalıp planı Şekil 10'da, örnek bina modeli tasarımda dikkate alınan parametreler Tablo 5'te verilmiştir.

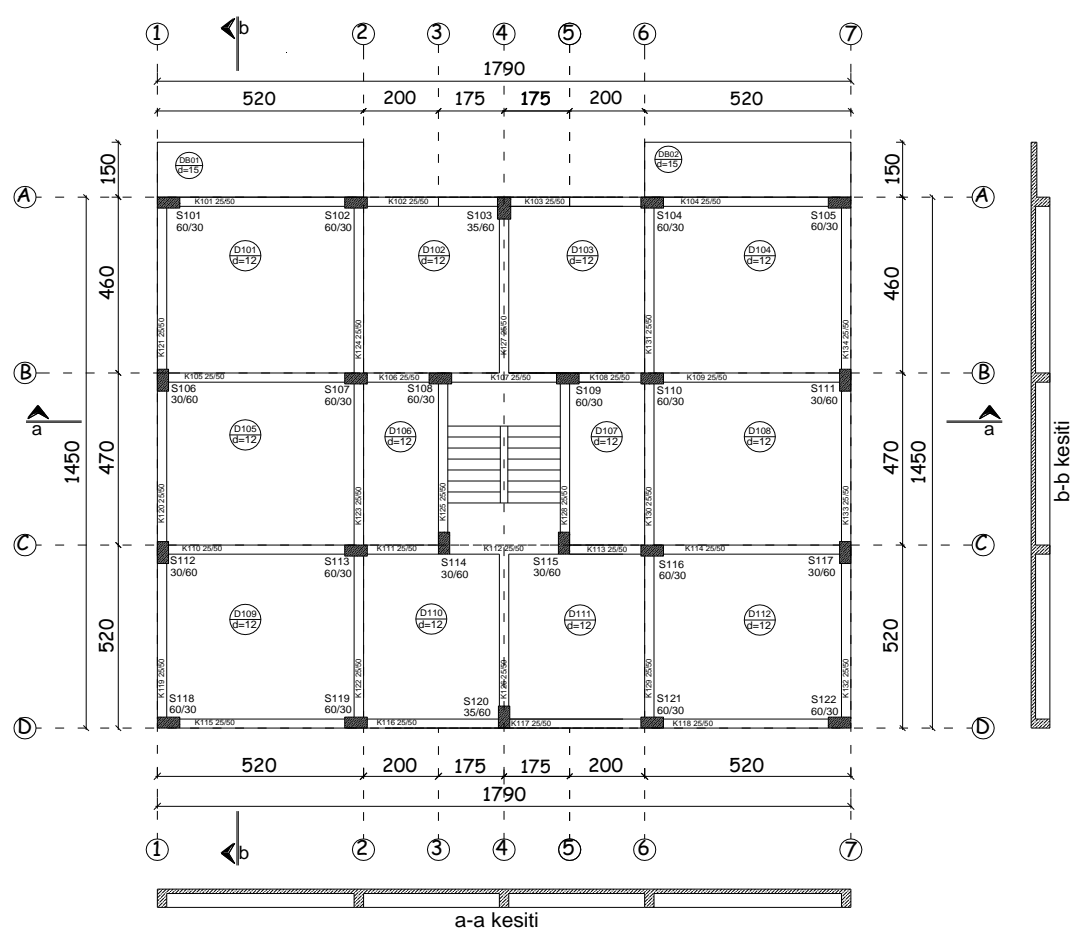

Şekil 10. Örnek betonarme çerçeve sistem bina modeli kalıp planı 
Tablo 5

Örnek çerçeve sistem betonarme bina modeli tasarım parametreleri

\begin{tabular}{|c|c|c|}
\hline Parametre & $\begin{array}{c}\text { DBYBHY } 2007 \\
\end{array}$ & TBDY 2019 \\
\hline Bina Türü & \multicolumn{2}{|l|}{ Betonarme Çerçeve Sistem (A11) } \\
\hline Kat Sayıs1 & \multicolumn{2}{|l|}{$5 \mathrm{Kat}(\mathrm{BK}+\mathrm{ZK}+3 \mathrm{NK})$} \\
\hline Kat Yüksekliği (hat) & \multicolumn{2}{|l|}{$3.0 \mathrm{~m}$} \\
\hline Bina Yüksekliği $\left(\mathrm{H}_{\mathrm{N}}\right)$ & \multicolumn{2}{|l|}{$12.0 \mathrm{~m}$} \\
\hline Bina Boyutları & \multicolumn{2}{|l|}{$17.90 \mathrm{~m} \times 14.50 \mathrm{~m}$} \\
\hline Kirişlerin Boyutları & \multicolumn{2}{|c|}{$25 \mathrm{~cm} \times 50 \mathrm{~cm}$} \\
\hline Kolonların Boyutları & \multicolumn{2}{|c|}{$30 \mathrm{~cm} \times 60 \mathrm{~cm}, 35 \mathrm{~cm} \times 60 \mathrm{~cm}, 30 \mathrm{~cm} \times 70 \mathrm{~cm}$} \\
\hline Döşemelerin Türü ve Boyutları & \multicolumn{2}{|c|}{ Plak Döşeme Odalarda $12 \mathrm{~cm}$, Balkon ve Sahanlıkta $15 \mathrm{~cm}$} \\
\hline Malzeme Sinıfları & \multicolumn{2}{|c|}{$\mathrm{C} 30 / 37, \mathrm{~S} 420$} \\
\hline Bina Önem Katsayısı (I) & \multicolumn{2}{|l|}{1} \\
\hline Deprem Yükü Diş Merkezliği & \multicolumn{2}{|l|}{$\% 5$} \\
\hline Haraketli Yük Katılım Katsayısı (n) & \multicolumn{2}{|l|}{0.3} \\
\hline Deprem Yer Hareket Düzeyi (DD) & - & DD-2 \\
\hline $\begin{array}{l}\text { Etkin Yer İvme Katsayısı }\left(\mathrm{A}_{0}\right) \\
\text { En Büyük Yer İvmesi }\left(\mathrm{P}_{\mathrm{GA}}\right)\end{array}$ & \multicolumn{2}{|l|}{$\begin{array}{l}\mathrm{A}_{0}=0.10 \mathrm{~g}(4 . \text { Deprem bölgesi }) \\
\mathrm{A}_{0}=0.20 \mathrm{~g} \text { (3. Deprem bölgesi) } \\
\mathrm{A}_{0}=0.30 \mathrm{~g} \text { (2. Deprem bölgesi) }\end{array}$} \\
\hline Bina Kullanım Sınıfı (BKS) & - & 3 \\
\hline Deprem Tasarım Sinıfi (DTS) & - & $\mathrm{S}_{\mathrm{DS}}$ 'ye göre değişmektedir. \\
\hline Bina Yükseklik Sınıfı (BYS) & - & 7 \\
\hline Taşıyıcı Sistem Davranış Katsayısı (R) & 8 & 8 \\
\hline Dayanım Fazlalığı Katsayısı (D) & - & 3 \\
\hline Bina Doğal Titreşim Periyodu (T) & $\mathrm{T}_{1 \mathrm{y}}=0.49 \mathrm{~s}$ & $\mathrm{~T}_{1 \mathrm{y}}=0.71 \mathrm{~s}$ \\
\hline Yerel Zemin Sinıfi & $\mathrm{Z1}, \mathrm{Z} 2, \mathrm{Z} 3, \mathrm{Z} 4$ & $\mathrm{ZA}, \mathrm{ZB}, \mathrm{ZC}, \mathrm{ZD}, \mathrm{ZE}$ \\
\hline
\end{tabular}

Çalışma kapsamında en sağlam zeminden en kötü zemine kadar zemin koşulları dikkate alınarak deprem yer hareketi düzeyi DD-2 için örnek betonarme bina modelinin TBDY 2019 ve DBYHY 2007'ye göre hesaplanan eşdeğer deprem yüklerinin birbiri ile karşılaştırılabilmesi için eşdeğer deprem yükleri (Vt) bina ağırlığına (W) oranlanmıştır. Edirne merkez ilçe ve ilçeleri için TBDY 2019 ve DBYBHY 2007'ye göre hesap sonucu bulunan eşdeğer deprem yükünün bina ağrılığına (Vt/W) oranlarının ortalama değerleri Tablo 6'da verilmiştir.

Tablo 6

Edirne merkez ilçe ve ilçelerinin TBDY 2019 ve DBYBHY 2007'ye göre hesaplanan (Vt/W) oranları

\begin{tabular}{lccccccccc}
\hline \multirow{2}{*}{ İçe Adı } & \multicolumn{3}{c}{ TBDY 2019 $(\mathbf{V t} / \mathbf{W})$ Oranları (\%) } & \multicolumn{3}{c}{ DBYBHY 2019 (Vt/W) Oranları (\%) } \\
\cline { 2 - 10 } & $\mathbf{Z A}$ & $\mathbf{Z B}$ & $\mathbf{Z C}$ & $\mathbf{Z D}$ & $\mathbf{Z E}$ & $\mathbf{Z 1}$ & $\mathbf{Z 2}$ & $\mathbf{Z 3}$ & $\mathbf{Z 4}$ \\
\hline Edirne & 3.40 & 3.40 & 6.38 & 9.97 & 16.71 & 3.31 & 3.76 & 3.98 & 3.98 \\
\hline Enez & 6.45 & 6.45 & 12.03 & 16.94 & 23.79 & 9.94 & 11.27 & 11.94 & 11.94 \\
\hline Havsa & 3.53 & 3.53 & 6.61 & 10.32 & 16.88 & 3.31 & 3.76 & 3.98 & 3.98 \\
\hline İpsala & 5.26 & 5.26 & 9.88 & 14.89 & 20.99 & 6.63 & 7.51 & 7.96 & 7.96 \\
\hline Keşan & 5.84 & 5.84 & 10.94 & 15.75 & 22.06 & 9.94 & 11.27 & 11.94 & 11.94 \\
\hline Lalapaşa & 3.14 & 3.14 & 5.93 & 9.36 & 15.84 & 3.31 & 3.76 & 3.98 & 3.98 \\
\hline Meriç & 4.07 & 4.07 & 7.63 & 11.71 & 18.11 & 3.31 & 3.76 & 3.98 & 3.98 \\
\hline Süloğlu & 3.24 & 3.24 & 6.06 & 9.06 & 16.10 & 3.31 & 3.76 & 3.98 & 3.98 \\
\hline Uzunköprü & 4.01 & 4.01 & 7.54 & 11.06 & 17.97 & 3.31 & 3.76 & 3.98 & 3.98 \\
\hline
\end{tabular}

Edirne merkez ilçe ve ilçelerinin örnek betonarme bina modeli için TBDY 2019 ve DBYHY 2007'ye göre hesaplanan eşdeğer deprem yükleri etkisinde meydana gelen tepe yer değiştirmelerinin ortalama değerleri Tablo 7'de verilmiştir. 
Tablo 7

Edirne merkez ilçe ve ilçelerinin TBDY 2019 ve DBYBHY 2007'ye göre hesaplanan tepe yer değiştirmeleri

\begin{tabular}{lccccccccc}
\hline \multirow{2}{*}{ İçe Adı } & \multicolumn{3}{c}{ TBDY 2019 En Büyük Yer Değiştirme (mm) } & \multicolumn{3}{c}{ DBYBHY 2007 En Büyük Yer Değiştirme (mm) } \\
\cline { 2 - 10 } & $\mathbf{Z A}$ & $\mathbf{Z B}$ & $\mathbf{Z C}$ & $\mathbf{Z D}$ & $\mathbf{Z E}$ & $\mathbf{Z 1}$ & $\mathbf{Z 2}$ & $\mathbf{Z 3}$ & $\mathbf{Z 4}$ \\
\hline Edirne & 3.50 & 3.56 & 6.43 & 9.61 & 15.79 & 1.66 & 2.08 & 2.42 & 2.42 \\
\hline Enez & 6.71 & 6.84 & 12.13 & 16.38 & 22.65 & 4.99 & 6.23 & 7.26 & 7.26 \\
\hline Havsa & 3.59 & 3.65 & 6.59 & 9.90 & 16.15 & 1.66 & 2.08 & 2.42 & 2.42 \\
\hline İpsala & 5.42 & 5.52 & 9.90 & 13.89 & 20.39 & 3.33 & 4.15 & 4.84 & 4.84 \\
\hline Keşan & 6.02 & 6.13 & 10.95 & 15.07 & 21.59 & 4.99 & 6.23 & 7.26 & 7.26 \\
\hline Lalapaşa & 3.23 & 3.29 & 5.98 & 9.02 & 15.00 & 1.66 & 2.08 & 2.42 & 2.42 \\
\hline Meriç & 4.14 & 4.24 & 7.60 & 11.21 & 17.67 & 1.66 & 2.08 & 2.42 & 2.42 \\
\hline Süloğlu & 3.31 & 3.37 & 6.08 & 9.55 & 16.09 & 1.66 & 2.08 & 2.42 & 2.42 \\
\hline Uzunköprü & 4.07 & 4.14 & 7.50 & 11.11 & 17.52 & 1.66 & 2.08 & 2.42 & 2.42 \\
\hline
\end{tabular}

TBDY 2019 ile DBYBHY 2007'ye göre örnek betonarme çerçeve bina modelinin Edirne Merkezi ve İlçeleri için hesap edilen eşdeğer deprem yüklerinin ve tepe yer değiştirmelerinin karşılaştırılması Tablo 8'de verilmiştir.

Tablo 8

Edirne merkez ilçe ve ilçelerinin TBDY 2019 ve DBYBHY 2007'ye göre hesaplanan (Vt/W) oranlarının ve tepe yer değiştirmelerinin karşılaştırılması

\begin{tabular}{|c|c|c|c|c|c|c|c|c|c|c|}
\hline \multirow[t]{2}{*}{ İlçe Adı } & \multicolumn{5}{|c|}{$\mathbf{V t}_{\text {TBDY2019}} / \mathbf{V t}_{\text {DBYBHY2007 }}$} & \multicolumn{5}{|c|}{$\boldsymbol{\delta}_{\text {TBDY2019 }} / \boldsymbol{\delta}_{\text {DBYBHY2007 }}$} \\
\hline & ZA-Z1 & ZB-Z1 & ZC-Z2 & ZD-Z3 & ZE-Z4 & ZA-Z1 & ZB-Z1 & ZC-Z2 & ZD-Z3 & ZE-ZE \\
\hline Edirne & 1.03 & 1.03 & 1.70 & 2.50 & 4.20 & 2.11 & 2.15 & 3.09 & 3.97 & 6.53 \\
\hline Enez & 0.65 & 0.65 & 1.07 & 1.42 & 1.99 & 1.35 & 1.37 & 1.95 & 2.26 & 3.18 \\
\hline Havsa & 1.07 & 1.07 & 1.76 & 2.59 & 4.24 & 2.16 & 2.20 & 3.17 & 4.09 & 6.67 \\
\hline İpsala & 0.79 & 0.79 & 1.32 & 1.82 & 2.64 & 1.63 & 1.66 & 2.39 & 2.87 & 4.17 \\
\hline Keşan & 0.59 & 0.59 & 0.97 & 1.32 & 1.85 & 1.21 & 1.23 & 1.76 & 2.08 & 2.95 \\
\hline Lalapaşa & 0.95 & 0.95 & 1.58 & 2.35 & 3.98 & 1.95 & 1.98 & 2.88 & 3.73 & 6.20 \\
\hline Meriç & 1.23 & 1.23 & 2.03 & 2.94 & 4.55 & 2.49 & 2.55 & 3.65 & 4.63 & 7.30 \\
\hline Süloğlu & 0.98 & 0.98 & 1.62 & 2.40 & 4.04 & 1.99 & 2.03 & 2.92 & 3.80 & 6.29 \\
\hline Uzunköprü & 1.21 & 1.21 & 2.01 & 2.90 & 4.52 & 2.45 & 2.49 & 3.61 & 4.59 & 7.24 \\
\hline
\end{tabular}

Tablo 5-8 incelendiğinde TBDY 2019'da betonarme bina taşıyıcı sistem elemanlarında çatlamış kesit rijitliklerinin kullanılması sebebiyle TBDY 2019'a göre elde edilen periyotlarda DBYBHY 2007'ye göre uzama olduğu, TBDY 2019'a göre bina tepe yer değiştirmelerinde Edirne'nin tüm ilçelerinde tüm zemin sınıflarında DBYBHY 2007'ye göre artış meydana geldiği görülmektedir. Tablo 6 ve Tablo 8 incelendiğinde örnek bina için TBDY 2019'a göre hesaplanan eşdeğer deprem yükünde Edirne'nin tüm ilçelerinde zayıf zemin sınıflarında (ZD, ZE) DBYBHY 2007'ye göre artış meydana geldiği, spektral ivme değerlerindeki değişime benzer şekilde DBYBHY 2007'ye göre 4. derece deprem bölgesindeki ilçelerde artış miktarı, Edirne'nin 2.ve 3. derece deprem bölgesindeki ilçelerine göre daha fazladır. Edirne Merkez, Havsa, Meriç, Uzunköprü ilçelerinde tüm zemin sınıfları için TBDY 2019'a göre hesap sonucu bulunan eşdeğer deprem yükü, DBYBHY 2007'ye göre artmış, İpsala, Lalapaşa ilçelerinde ZA, ZB sınıfı için TBDY 2019'a göre hesap sonucu bulunan eşdeğer deprem yükü DBYBHY 2007'ye göre azalırken diğer zemin sınıflarında artmış, Keşan ilçesinde ZA, ZB ve ZC sınıfı için TBDY 2019'a göre hesap sonucu bulunan eşdeğer deprem yükü DBYBHY 2007'ye göre azalırken diğer zemin sınıflarında artmıştır. Örnek bina için TBDY 2019'a göre hesaplanan eşdeğer deprem yüklerinde DBYBHY 2007'ye göre değişimin sebebi önceki bölümde verilen yatay tasarım spektrum karşılaştırmalarından görülebilmektedir. Çalışmada elde edilen yatay tasarım spektrum eğrileri Edirne merkezi ve ilçeleri için geçerli olduğundan ve eşdeğer deprem yükleri ile tepe yer değiştirmeleri örnek bina modeli için elde edildiğinden farklı bölgelerde ve farklı periyoda sahip binalar için elde edilen bu oranların değişebileceği unutulmamalıdır. 


\section{Sonuçlar}

Edirne merkezi ve ilçelerinin tamamında TDBY 2019'a göre en büyük yer ivmesi (PGA) değerleri DBYHYHY 2007'ye göre artmıştır. DBYHBHY 2007'ye göre 4. derece deprem bölgesindeki Edirne ilçelerinde ortalama 1.66-1.99 kat artış, 3. derece deprem bölgesindeki ilçelerde ortalama 1.40 kat artış ve 2. derece deprem bölgesindeki ilçelerde ortalama 1.03-1.21 kat artış meydana gelmiştir. En büyük artışın TBDY 2007'ye depremselliği az olan 4. derece deprem bölgesindeki ilçelerde olduğu gözlenmiştir.

TBDY 2019 yönetmeliğine göre en büyük spektral ivme değeri, Enez ilçesinde ZC sınıfında, diğer ilçelerde ise ZE zemin sınıfında görülmektedir. Spektral ivme katsayıları aynı deprem bölgesi için DBYBHY 2007'de farklı zemin sınıflarına göre değişmezken, TBDY 2019'da spektral ivme katsayıları zemin sınıfına göre değişmektedir. TBDY 2019'a göre Edirne merkezi ve ilçeleri için belirlenen tasarım spektral ivme değerleri özellikle zayıf zeminlerde DBYBHY 2007'ye göre belirlenen değerlere kıyasla artış göstermektedir.

TBDY 2019 spektral ivme değerlerinde DBYBHY 2007'ye göre artış DBYBHY 2007'ye göre 4. derece deprem bölgesinde bulunan Edirne ilçelerinde ortalama \%220, 3. derece deprem bölgesindeki ilçelerde \%90 ve 2 . deprem bölgesindeki ilçelerde ise ortalama \%35'tir. Spektral ivmelerdeki artışın, DBYBHY 2007'ye göre 4. derece deprem bölgesinde en fazla, 3. derece deprem bölgesinde daha az ve 2. derece deprem bölgesinde ise en az olduğu görülmektedir. Türkiye Deprem Tehlike Haritası (TDTH)'na göre Edirne merkezi ve ilçelerinin tamamında yürürlükten kalkan deprem tehlike haritasına göre daha yüksek sismik tehlike öngörülmektedir. Edirne merkezi ve ilçelerinin TBDY 2019 spektral ivme değerlerinde DBYBHY 2007'ye göre meydana gelen artışın binalara etki edecek deprem yüklerini ne oranda değiştireceğinin bina özelinde çözüm yapılmadan kestirilmesi mümkün olmasa da DBYBHY 2007'ye göre 4. derece deprem bölgesinde ve zayıf zeminlerde bulunan mevcut yapı stoğunun deprem performanslarının gözden geçirilmesi gelecekte olası depremlerde mal ve can kayıplarını önlemek açısından yararlı olacaktır.

\section{Yazar Katkıları}

Burak Özşahin: Çalışmanın tüm aşamalarını gerçekleştirmiştir ve yazmıştır.

\section{Çıkar Çatışması}

Yazar çıkar çatışması bildirmemiştir.

\section{Kaynaklar}

Akansel, V. H., Sosyal, B. F., Kadaş, K. ve Gülkan, H. P. (2020). An evaluation of the 2018 seismic hazard map of Türkiye on the basis of spectrum intensity, Turkish Journal of Earthquake Research, 2(2), 115137. https://doi.org/10.46464/tdad.737433

Bozer, A. (2020). Tasarım spektral ivme katsayılarının DBYBHY 2007 ve TBDY 2018 yönetmeliklerine göre karş1laştırılmas1, Dicle Üniversitesi Mühendislik Fakültesi (DÜMF) Dergisi, 11(1), 393-404. https://doi:10.24012/dumf.559965

Coğrafya Harita (2021). Coğrafya Harita. Erişim adresi: http://cografyaharita.com/turkiye mulki idare haritalari2.html. Erişim tarihi:23.07.2021

Darılmaz, K. (2018). Depreme dayanıklı betonarme binaların tasarımına giriş, İstanbul: Sage Yayınevi.

DBYBHY (2007). Deprem Bölgelerinde Yapılacak Binalar Hakkında Yönetmelik, Bayındırlık ve İskan Bakanlığı, Ankara. Erişim adresi: https://www.resmigazete.gov.tr/eskiler/2007/03/20070306-3.htm

İncetaş, S. ve Tanrıkulu, K. (2002). Binaların birinci doğal titreşim periyodunun yaklaşık olarak belirlenmesi. Erişim adresi: https://fbe.cu.edu.tr/tr/makaleler/2001/binalarinbirinci.pdf. Erişim tarihi: 23.07.221

Karaca, H., Oral, S. M. ve Erbil, M. (2020). Yapısal tasarım bağlamında 2007 ve 2019 deprem yönetmeliklerinin karşılaştırması, Niğde Örneği, Niğde Ömer Halisdemir Üniversitesi Mühendislik Bilimleri Dergisi, 9(2), 898-903. https://doi.org/10.28948/ngumuh.667365 
Karasin, İ. B., Işık, E., Demirci, A. ve Aydın, M. C. (2020). Coğrafi konuma özel tasarım spektrumlarının betonarme yapı performansına etkisi, Dicle Üniversitesi Mühendislik Fakültesi Mühendislik Dergisi, 11(3), 1319-1330. https://doi.org/10.24012/dumf.682377

Keskin, E. ve Bozdoğan, K. B. (2018). 2007 ve 2018 Deprem yönetmeliklerinin Kırklareli özelinde değerlendirilmesi, Kırklareli Üniversitesi Mühendislik ve Fen Bilimleri Dergisi, 4(1), 74-90. Erişim adresi: https://dergipark.org.tr/tr/pub/klujes/issue/37436/421614

Koçer, M., Nakipoğlu, A., Öztürk, B., Al-Hagri, M. H. ve Arslan, M. H. (2018). Deprem kuvvetine esas spektral ivme değerlerinin TBDY 2018 ve TDY 2007'ye göre karş1laştırılması, Selçuk Üniversitesi Selçuk-Teknik Dergisi, 17(2), 43-58. Erişim adresi: http://sutod.selcuk.edu.tr/sutod/article/view/437

Nemutlu, Ö. F., Balun, B., Benli, A. ve Sarı, A. (2020). Bingöl ve Elazı̆̆ illeri özelinde 2007 ve 2008 Türk Deprem Yönetmeliklerine göre ivme spektrumlarının değişiminin incelenmesi, Dicle Üniversitesi Mühendislik Fakültesi (DÜMF) Dergisi, 11(3), 1341-1356. https://doi.org/10.24012/dumf.703138

Özşahin, B. (2021). Türkiye bina deprem yönetmeliği 2019'a göre Kırklareli için deprem yüklerinin değerlendirilmesi, Düzce Üniversitesi Bilim ve Teknoloji Dergisi, 9(2), 836-863. https://doi.org/10.29130/ dubited.768494

Öztürk, M. (2018). 2018 Türkiye bina deprem yönetmeliği ve Türkiye deprem tehlike haritası ile ilgili İç Anadolu Bölgesi bazında bir değerlendirme, Selçuk Üniversitesi Selçuk-Teknik Dergisi, 17(2), 31-42. Erişim adresi: http://sutod.selcuk.edu.tr/sutod/article/view/434/651

Seyrek, E. (2020). Yeni Türkiye sismik tehlike haritasının Ege Bölgesi için değerlendirilmesi, Niğde Ömer Halisdemir Üniversitesi Mühendislik Bilimleri Dergisi, 9(1), 414-423. https://doi:10.28948/ngumuh.617268

Sta4Cad V 14.1 (2021). Structrual analysis for computer aided design program, Sta Bilgisayar Mühendislik Müşavirlik Ltd. Şti., İstanbul. Erişim adresi: http://www.sta4.net/.

Sucuoğlu, H. (2019). 2019 Türkiye bina deprem yönetmeliğinde başlıca yenilikler, Türk Deprem Araştırma Dergisi, 1(1), 63-75. Erişim adresi: https://dergipark.org.tr/en/pub/tdad/issue/46355/567261

Sümer, Y. ve Hamsici, M. (2020). Çok katlı betonarme binalarda 2018 deprem yönetmeliği ile tanımlanan spektrum eğrilerinin etkisi, Academic Platform Journal of Engineering and Science, 8(2), 349-354. https://doi.org/10.21541/apjes.641250

Şahin, H., Durucan, A. R. ve Durucan, C. (2020). Deprem bölgesi haritasından kontur içeren deprem tehlike haritasına geçişin çeşitli yapılarda tasarım ve analiz deprem yükü taleplerine etkisi, Fırat Üniversitesi Mühendislik Bilimleri Dergisi, 32(2), 325-334. https://doi.org10.35234/fumbd. 691917

TBDY (2019). Türkiye Bina Deprem Yönetmeliği, T.C. Başbakanlık Afet ve Acil Durum Yönetimi Başkanlığı, Ankara. Erişim adresi: https://www.resmigazete.gov.tr/eskiler/2018/03/20180318M1.pdf

T.C. Başbakanlık Afet ve Acil Durum Yönetimi Başkanlığı Türkiye Deprem Tehlike Haritaları İnteraktif Web Uygulamas1. Erişim adresi: https://tdth.afad.gov.tr/. Erişim tarihi:23.07.2021

TS 500 (2000). Betonarme Yapıların Tasarımı ve Yapım Kuralları, Türk Standartları Enstitüsü, Ankara. Erişim adresi: https://www.tse.org.tr/ 